\title{
Do Electoral Handouts Affect Voting Behavior?*
}

\author{
Jenny Guardado R. \\ Department of Politics \\ New York University \\ jenny.guardado@nyu.edu
}

\author{
Leonard Wantchékon \\ Department of Politics \\ Princeton University \\ lwantche@princeton.edu
}

March 3, 2014

\begin{abstract}
The literature on vote-buying assumes a complete transaction of cash for votes. While there is ample evidence that candidates do target certain voters with cash handouts, it is unclear whether these actually result in higher turnout and voteshares for the distributing party. In this paper we argue that in settings with low level of monitoring by political parties, such as many African countries, parties might be unable to provide a sufficient level of bribes to ensure sustained cooperation from voters. Theoretically, we show that even in infinitely repeated settings low monitoring leads to prohibitively high level of bribes thus explaining why incomplete transactions of cash for votes are so prevalent. Empirically, we find that cash handouts have no effect on either turnout or vote-shares when using different matching techniques and including constituency-level fixed effects during the 2011 Beninese presidential election. We cross-validate these results with two additional surveys from Benin and Kenya. These findings suggest that vote-buying in sub-Saharan Africa is better explained as an incomplete transaction between candidates and voters, and that constituency-level variables such as patronage or targeted public goods have much stronger effects on voting behavior than electoral handouts.
\end{abstract}

\footnotetext{
*We thank the participants of the 2012 Columbia-NYU African Political Economic Research Seminar (CAPERS) and to Alex Bolton, Chris Blattman, Macartan Humphreys, Kimuli Kasara, Elisabeth Sperber, David Stasavage, Shana Warren, Emily West as well as participants of the 2013 Midwest Political Science Association Conference (MPSA) and special thanks to our discussant Gwyneth Hartman McClendon. All remaining errors are our own.
} 


\section{Introduction}

Vote-buying is defined as a transaction whereby candidates distribute private goods such as cash and gifts in exchange for electoral support or higher turnout (Brusco et al. 2004; Finan and Schechter 2012; Kramon 2009; Stokes 2005; Stokes et al. 2012; Nichter 2008). ${ }^{1}$ The direct implication of this definition is that vote-shares and turnout would have been lower in the absence of electoral handouts. While there is ample evidence that candidates do target certain voters with cash handouts, it is unclear whether these handouts actually result in greater turnout or higher vote-shares in favor of the distributing candidate. In this paper, we use a modified version of the vote-buying model to investigate the conditions under which voter might agree to vote for the distributing party. In addition, we use evidence from Benin and Kenya to investigate whether such conditions are fulfilled and vote-buying, as defined above, actually takes place.

We use the framework developed by Dekel et. al. (2008; 2009) to establish the conditions under which the exchange of bribes for votes might become an equilibrium. We find that in the presence of low monitoring by political parties, cash in exchange for votes cannot be an equilibrium in one-shot interactions. Even in the case of repeated interactions, the presence of low monitoring renders the bribes to be paid for votes as prohibitively high thus unlikely to be fulfilled by cash-strapped parties. This situation is worsened when more than one party is bribing to obtain votes. We then investigate empirically whether vote-buying actually leads to any visible effect on vote-shares or turnout. We use three post-electoral surveys to investigate the effectiveness of votebuying: the first, an original survey conducted after the 2011 presidential election in Benin (see Wantchekon 2012); the second and third from Round 5 of the Afrobarometer survey conducted during 2012 in Benin and Kenya during 2012, respectively. While the Benin Afrobarometer survey has the unique feature that it measures whether handouts were offered by one or more parties, the Kenya data allows for additional robustness checks of our results. That is, given the similarity in the Afrobarometer questions across countries, the Kenya data helps us cross-validate our findings across two different surveys and two different countries.

\footnotetext{
${ }^{1}$ For example, Brusco et al. (2004: 67) defines vote-buying "as the proffering to voters of cash or (more commonly) minor consumption goods by political parties, in office or in opposition, in exchange for the recipient's vote." Similarly, Finan and Schechter (2012: 864) define vote-buying as "[offered] goods to specific individuals before an election in exchange for their votes." Kramon (2009: 4) defines it as "the distribution of particularistic or private material benefits with the expectation of political support." Nichter (2008: 20) defines vote-buying (as opposed to "turnout buying") as "exchanging rewards for vote choices." Banerjee et al. (2011: 14) considered vote-buying as any instance by which "cash, liquor, food, clothes or milk/refreshments [are distributed] as enticement [to vote or mobilize]." Finally, Stokes et al. (2012: 17) have recently labeled as vote-buying the situation in which "political machines may treat or bribe to persuade people to vote for them."
} 
Our empirical approach is based on the premise that monitoring by political parties in African countries is actually quite low: $82 \%$ of respondents ${ }^{2}$ across 31 African countries report it to be very to somewhat unlikely for powerful actors to find out how they voted. Specially in Benin and Kenya, perceptions of vote privacy are that of $91 \%$ and $88 \%$, respectively. Based on this fact, our empirical strategy aims to discern whether political parties are able to provide a bribe such that it can sustain cooperation (e.g. votes) from targeted voters. However, compelling evidence in favor of vote-buying as an effective strategy should involve the construction of a valid counterfactual of how targeted voters would have behaved in the absence of cash handouts. For this purpose, we use different matching techniques to account for the non-random targeting of cash handouts and to measure electoral behavior when no private rewards are involved. To improve the efficiency of our matching estimators, we compare individuals with similar characteristics belonging to the smallest politically relevant unit - the electoral district. This approach incorporates the counterpart of district fixed-effects within a matching framework and controls for district-level differences in observable and unobservable traits that may greatly influence electoral behavior. Such differences might be driven by targeted spending, strategic campaigning, level of party competition, or the quality of local institutions. Matching techniques that ignore district-level traits may pair off individuals with similar personal characteristics but different (district-level) political conditions. We argue that previous studies that have found a positive effect of cash handouts may in fact be capturing the effect of targeted spending and other district-level political variables. Therefore, a rigorous examination of the effectiveness of vote-buying should use matched data and control for time-invariant district characteristics.

To show the validity of this approach, we estimate the effect of cash distribution on voter turnout and electoral choices using both matched and unmatched data. Consistent with current literature, we find that cash distribution increases votes and turnout (Brusco et al. 2004) when using unmatched data. However, when we use matched data and introduce district-level fixed effects, we find no statistically significant difference in behavior between individuals who received cash handouts and those who did not. This evidence suggests that district-level factors might mitigate the effect of cash handouts. Such factors could include targeted spending prior to the election, as has been discussed extensively in the context of American politics (Herron and Theodos 2004; Denemark 2000; Dahlberg and Johansson, among others $)^{3}$, or local economic conditions which influence voting (Tucker 2006).

We cross-validate these results with the Afrobarometer Round 5 survey data for Benin.

\footnotetext{
${ }^{2}$ This figure excludes missing observations and those who responded with don't know.

${ }^{3}$ See also: Ansolabehere and Snyder 2006, Horiuchi and Lee 2008; Levitt and Snyder 1997; and Berry, Burden and Howell 2010.
} 
As with the 2011 survey, we find a strong effect of electoral handouts on voter turnout in the unmatched data but no effect in the matched data. This suggests that, at least in the context of our study, the vote-buying transaction is incomplete. The same results hold when using the Kenyan Round 5 Afrobarometer survey data. We show that one possible reason for the null effect of cash distribution is that a typical voter may receive multiple cash offers, therefore, the potential bribe to be paid by each party is higher than when no competition is higher thus unlikely to be fulfilled by either party. We therefore compare the effect of single versus multiple offers and we find that, while there is a stronger effect of incentives given by only one party (in contrast to many), the results are not robust when using different matching techniques. Moreover, because cash handouts are very often distributed by multiple parties to the same constituency, the overall effect of these more targeted efforts is small. Our result implies that local institutions or targeted local provision of public goods might be more effective in influencing voting behavior than cash distribution alone.

The paper contributes to the current literature in several ways. First, it builds on the vote-buying literature by closely examining the actual effect of cash handouts on voting behavior. Although numerous studies have documented the targeting strategies of politicians to "purchase" votes (Stokes 2005; Nichter 2008; Finan and Schechter 2012; Calvo and Murillo 2004; Brusco et al. 2004), none have theoretically examined the consequences of low-monitoring for the prevalence of vote-buying. In particular, we examine how does low monitoring indeed renders the bribe to be paid by parties as impossibly high and therefore unlikely to be fulfilled by political parties. Second, we conduct a counterfactual analysis of the complete vote-buying transaction based on within-district comparisons. That is, we empirically explore whether vote-buying actually "buys" votes instead of assuming that whoever receives electoral handouts will choose to vote for the distributing candidate. Our approach improves the measurement of the causal effect of cash handouts by providing a formal treatment of counterfactuals in the context of the cash-for-votes literature. We address the question "Would voters who receive cash behave differently if they had not?" by estimating the average treatment effect on the treated via matching on observables. We also account for community-level traits which may reflect strategic spending on public goods before the election. As such, we control for pre-electoral clientelist practices and other district-level variables. ${ }^{4}$ Third, we empirically test theoretical insights from the vote-buying framework, by explicitly investigating the effect of competing offers on voting behavior. We show both theoretically and empirically that competition by political parties renders vote-buying more unlikely due to the higher prices to be paid. The evidence from Benin shows that the proportion of individuals

\footnotetext{
${ }^{4}$ Acemoglu et al. (2008) used a similar approach in their critique of modernization theory.
} 
who received money from more than one party actually outnumbers those who received money from a single source - a scenario that has been labeled "empirically unusual" (by Stokes 2005; Nichter 2008), but is consistent with findings in the theoretical literature on vote-buying (Dekel, Jackson and Wolinsky 2008) and supported by the Afrobarometer data of Benin. Fourth, and finally, the paper contributes to the literature on clientelism by isolating the effect of cash handouts from that of targeted spending and other districtlevel variables. When we observe differences in voting behavior as a result of clientelist redistribution, which may involve both cash handouts and targeted local public goods, we need to find out whether this change is driven by appeals to the individual or the community. In other words, we need to find out whether a vote of the rural poor in Africa or elsewhere is "bought" with a mere couple of bills or with targeted spending on local schools or road maintenance. If it is the latter, as the evidence in this paper suggests, then it could be argued that these voters care much more about policy, particularly local public goods, than previously acknowledged in the vote-buying literature.

The paper is organized as follows. In Section 2 we conduct a survey of the literature distinguishing among works focusing on the distributive strategies of politicians and those looking at the electoral effects of cash distribution. In Section 3 we provide a theoretical framework to analyze vote-buying along with its main implications. In Section 4 we provide an overview of the data and analytical methodology. In Section 5 we provide an empirical example based on the 2011 presidential elections in Benin and Kenya. Finally, Section 6 discusses the results and concludes.

\section{Literature Review}

The literature on vote-buying has focused on the strategic targeting of cash handouts, but has devoted less attention to voter response to electoral incentives. For example, Stokes (2005) thoroughly documents the distributional patterns of those who receive material gifts in Argentina finding that those who are mildly opposed to the distributing candidate and those with low incomes are likely to be targeted. Similar results are found by Kramon (2009) in Kenya where swing voters and those with low-incomes are more likely to be targeted for mobilization purposes. Brusco et al. (2004) and Calvo and Murillo (2004) also provide evidence that political parties target low-income individuals. In contrast, Nichter (2008) finds that political parties target passive constituencies to increase their vote share, while Finan and Schechter (2012) provide evidence of how party operatives target reciprocal individuals to ensure their compliance at the polling station. Although these studies emphasize the characteristics parties target with bribes, it relies on assumptions about the effect of cash handouts on voting behavior. 
A second group of studies relies on experimental frameworks to establish the causal effect of cash handouts on voting behavior. However, natural experiments on the topic are scarce and experimental designs that directly randomize cash handouts to influence voting behavior may raise ethical concerns. Due to these constraints, field experiments typically randomize some aspect of the voting decision process rather than the direct distribution of electoral handouts. For example, Vicente (2012) randomizes the distribution of anticorruption (e.g. anti vote-buying) information to assess indirectly the effect of cash handouts on electoral behavior. Similarly, Kramon (2012) randomly provides voters with information on whether a given politician engages in vote-buying to assess subsequent electoral support. However, such approaches introduce an additional layer of complexity (e.g. information campaigns, perceptions of the negativity of corruption) that makes a straightforward interpretation of the observed effect difficult.

Finally, a third group of related studies depart from the traditional explanations for why parties distribute electoral handouts (e.g. to purchase votes) and explore alternative accounts. One set of explanations put forward in the literature focuses on enhancing credibility (Schaffer 2002; Keefer and Vlaicu 2008) or showing political strength (Kramon 2010). According to these studies, handouts by politicians need not to have an effect on the specific voter targeted, but rather signal to the entire population the credibility of their campaign promises (Banegas 2002; Nugent 2007; Schaffer and Schedler 2007). Extending this logic, even if voters are neither offered nor directly receive money, they need only be aware of the vote-buying activities as credible proof of the politicians' good intentions. For instance, Kramon (2012) finds that spreading information that randomly attributes vote-buying activities to politicians actually bolsters electoral support for them, even if voters have not received a direct benefit. The mechanism he puts forward is one of costly signaling of future performance. Although we do not directly address this question, our theoretical framework provides some insights for why politicians might still provide handouts even if these fail to actually purchase votes. Based on the prisoner's dilemma type of interaction between voters and party machines, political parties might still find it in their interest to distribute handouts, particularly in the presence of other parties doing the same thing as a strategy to prevent other parties from (probably) winning / buying such votes.

In terms of theoretical contributions, the literature on vote-buying has mostly focused on the conditions under which bribes may sustain cooperation (e.g. votes) in repeated interaction settings. One assumption underpinning this analysis is that parties are able to monitor vote-choices (Stokes 2005) or at least observe turnout (Nichter 2008). Under these conditions, there exists a level a bribes that will satisfy the voter and guarantee either votes or turnout in favor of the machine or distributing candidate. In this framework, 
we relax this assumption by political parties and find that in a context were monitoring is low to minimal the level of the bribe needed to sustain cooperation is prohibitively high from the standpoint of the voter. Therefore, even if the machine provides a handout, this is unlikely to satisfy voters which would then have the incentive to vote their conscience. Similar results are obtained in the case in which more than one party machine is competing in bribes to win voters.

In the light of the shortcomings of current empirical approaches, we argue for the need to assess the prevalence of vote-buying based on its effect on voting behavior, not merely on the distribution of cash handouts. To do so, vote-buying should be reexamined along two lines: towards the use of quasi-experimental designs, or towards matching techniques that directly address the counterfactual of the vote-buying phenomenon. What these approaches can do is to account for non-random exposure to handouts; that is, those who received cash from politicians and those who do not differ in ways that may be correlated with voting behavior. For instance, an endogeneity concern arises if individuals highly interested in politics attend more political rallies, thus increasing their likelihood both of being offered a reward and of turning out to vote. In this case, it is not the reward driving turnout, but rather a prior interest in politics. To address this and similar concerns, in this paper we rely on different matching procedures to account for such non-random assignment. Although matching is not a solution for potential unobservables influencing both the treatment (cash handouts) and the outcome (vote behavior), they can improve regression approaches in the estimation of the average treatment effect among the treated (ATT) - which is our question of theoretical interest - by weighting more heavily the characteristics of those who are "treated" (Angrist and Pischke 2008).

\section{Theoretical Framework}

To motivate the empirical analysis we present a simple framework to understand individual vote choices in the presence of vote-buying based on that of Dekel et.al. (2008; 2009). Unlike other models of vote or turnout buying (Stokes 2005; Nichter 2008) the focus here is primarily on the vote-choices of individuals, rather than in the strategies of political parties. In this framework, voter $i$ obtains a utility $U_{i}^{x}$ for voting for party $x$ equal to the sum of its intrinsic preferences for that party $\left(V_{i}^{x}\right)$ plus the potential bribe given by party $x$ to vote in its favor $\left(p_{i}^{x}\right)$. Similarly, the individual utility of voting for party $y$ can be represented by $U_{i}^{y}=V_{i}^{y}+p_{i}^{y}$. Thus, in the presence of strong intrinsic preferences, payments to sway voters must be higher than if preferences were lower. Now, let's suppose that only one party, say $y$, is engaging in vote-buying whereas party $x$ is not $\left(p_{i}^{x}=0\right)$. In the presence of a secret ballot, it is crucial for party $y$ to engage in 
monitoring activities to corroborate that voters are indeed complying with their side of the deal. If the party finds out that voter $i$ has reneged, they punish her with a one-time cost $d$. Therefore, from the perspective of voter $i$ the expected utility from voting for each party becomes:

$$
\begin{gathered}
U_{i}^{x}=m\left(V_{i}^{x}-d+p_{i}^{y}\right)+(1-m)\left(V_{i}^{x}+p_{i}^{y}\right) \\
\text { and, } \\
U_{i}^{y}=V_{i}^{y}+p_{i}^{y}
\end{gathered}
$$

In equilibrium, voter $i$ will choose the distributing party $y$, whenever the expected punishment is greater than the difference in the preferences for each party:

$$
m d>V_{i}^{x}-V_{i}^{y}
$$

The point to highlight is that the relevant determinants of vote-choice are the intrinsic preferences and the expected punishment if caught, but not the size of the bribe given by party $y$. The reason for this is that one-time interactions with payments given upfront are susceptible to defection if monitoring or the punishment is small. Empirically, this suggests that in contexts where monitoring by political parties is low or negligible, votechoice will be driven by the intrinsic valuations of parties not the size of the bribe. This is the case of many African countries where party machines are either completely absent or short-lived and where the distribution of electoral handouts can be almost considered as if random. Just to illustrate, in the latest Afrobarometer series (Round 5), the question was asked: How likely do you think it is that powerful people can find out how you voted, even though there is supposed to be a secret ballot in this country? The answer across 31 African countries is that $82 \%$ of those not missing or unknown find it either not at all likely or not very likely for powerful people to find out how they voted, while only $18 \%$ find it somewhat likely or very likely. 
Figure 1: Vote Disclosure in Selected African Countries

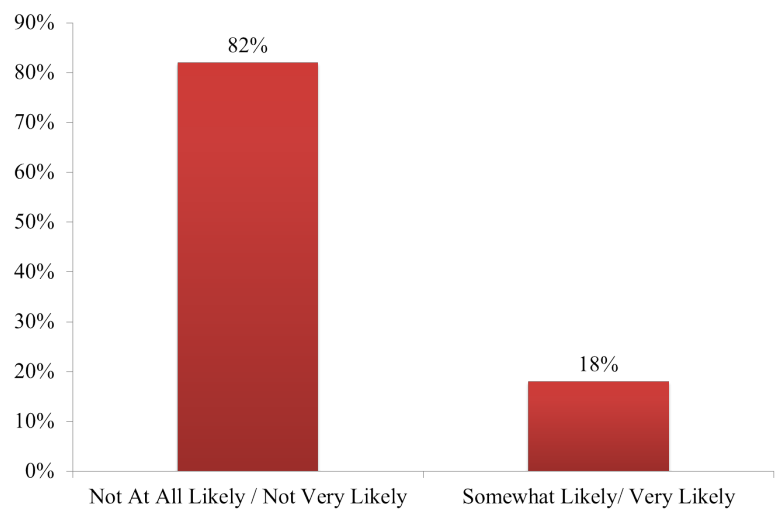

Question: How likely do you think it is that powerful people can find out how you voted, even though there is supposed to be a secret ballot in this country? Source: Afrobarometer Round 5 (2010-2012). Countries: Algeria 2013, Benin 2012, Botswana 2012, Burkina Faso 2012, Burundi 2012, Cameroon 2013, Cape Verde 2011, Cote d'Ivoire, Ghana 2012, Guinea, Kenya 2011, Lesotho 2012, Liberia 2012, Madagascar 2013, Malawi 2012, Mali 2012, Mauritius 2012, Morocco 2013, Mozambique 2012, Namibia 2012, Niger 2013, Nigeria 2012, Senegal 2013, Sierra Leone 2012, South Africa 2011, Swazilandia 2013, Tanzania 2012, Togo 2012, Uganda 2012, Zambia 2012, Zimbabwe 2012. HTML: http://www.afrobarometer-onlineanalysis.com/aj/AJBrowserAB.jsp

Moreover, when looking at particular countries and comparing whether those who are targeted with electoral incentives think it is more likely they find out how they vote than those who are not targeted we find no difference in percentages to those in the general population. Put together, this suggests that monitoring by political parties, or any political actors might be actually quite low or imperfect. Therefore suggesting that without a political machine, the transaction of cash for votes will remain incomplete due to the lack of enforcement. In the rest of this section we will analyze the theoretical consequences of low monitoring for existing theories of vote-buying.

\section{Vote Buying with Repeated Interactions}

First, let's analyze which would be the vote choice of individuals in the context of repeated interactions. That is, assuming there is a permanent political "machine" which can identify voters, distribute private benefits, and at least partly, monitor the vote choices of these individuals. Unlike one-shot interactions where enforcing transactions is difficult, it is possible for vote-buying to occur if interactions are infinitely repeated. The purpose of this exercise is to highlight two key aspects overlooked in the literature: first, the effect of low monitoring on the size of the bribes necessary to purchase all future votes; and second, assess the impact of more than one political party distributing private rewards. 
We follow the approach advanced in the literature (Stokes 2005; Nichter 2007), and assume an infinitely repeated prisoner's dilemma where parties follow a grim-trigger strategy to investigate the conditions necessary to induce cooperation towards the party distributing handouts $(y)$. Similar to the previous case we assume a cost of monitoring for party $y$ represented by $m$ while the discount factor of the future by voter $i$ is given by $\beta$. Under this characterization, the distributing party $y$ can ensure sustained cooperation from voter $i$ whenever the following is true:

$$
\frac{1}{1-\beta}\left(V_{i}^{y}+p_{i}^{y}\right) \geq V_{i}^{x}+p_{i}^{y}+\frac{\beta}{1-\beta}\left[m\left(V_{i}^{x}\right)+(1-m)\left(V_{i}^{y}+p_{i}^{y}\right)\right]
$$

Where the left hand side of this inequality depicts the benefits to voter $i$ from cooperating in each stage. The right hand side reflects the benefits of defecting in any given stage plus the discounted value of future rewards. In particular, the rewards obtained if with probability $m$ she is caught and only obtains the intrinsic value of voting for the opposition party $x$ in all subsequent stages. Or, if with probability $1-m$ she is not caught but continues voting for party $y$ indefinitely. Simplifying (1) we obtain:

$$
p_{i}^{y} \geq \Phi\left(V_{i}^{x}-V_{i}^{y}\right)
$$

Where $\Phi=\frac{1-\beta+m \beta}{m \beta}$. This result yields similar comparative statics of those of Stokes (2005) and Nichter (2008) in terms of monitoring: the size of the bribe is inversely correlated with the probability of detection. However, the implication we want to highlight is that in the context of low monitoring the price to be paid for each vote from the perspective of voter $i$ is quite large. Since parties prefer to pay the least amount possible, let $\overline{p_{i}^{y}}$ be the level of bribes such that (2) holds at equality. In this case, there exists a threshold of monitoring $m^{*}$ below which the size of the bribe is infinite. Specifically, the right hand side of the relationship goes to $\infty$ as $\Phi \rightarrow \infty$ if $m \rightarrow 0$. The implication is that for the distributing party to sustain cooperation under low monitoring, the value of the bribe to be paid is significantly high. If such level is not paid, the voter may just take the bribe offered and vote its conscience given the low probability of ever being caught. In other words, although the machine may only pay what a single vote is worth from its perspective, this might not be enough to guarantee cooperation from the voter.

\section{Vote-Buying Competition}

Once we show how the size of the bribe should be infinitely high to induce sustained cooperation from voter $i$ in the presence of low monitoring, we now consider the case in which both parties engage in a bid war such that party $x$ will also distribute payments $p_{i}^{x}$ to voter $i$ in exchange for her vote. In contrast to the focus of the literature on 
a single "machine" handouts are frequently distributed by more than one party, thus further compromising the completeness of the vote-buying transaction. Below we see how a majority of the reported handouts distributed in Benin come from more than one party.

Figure 2: Is there only "one" machine?

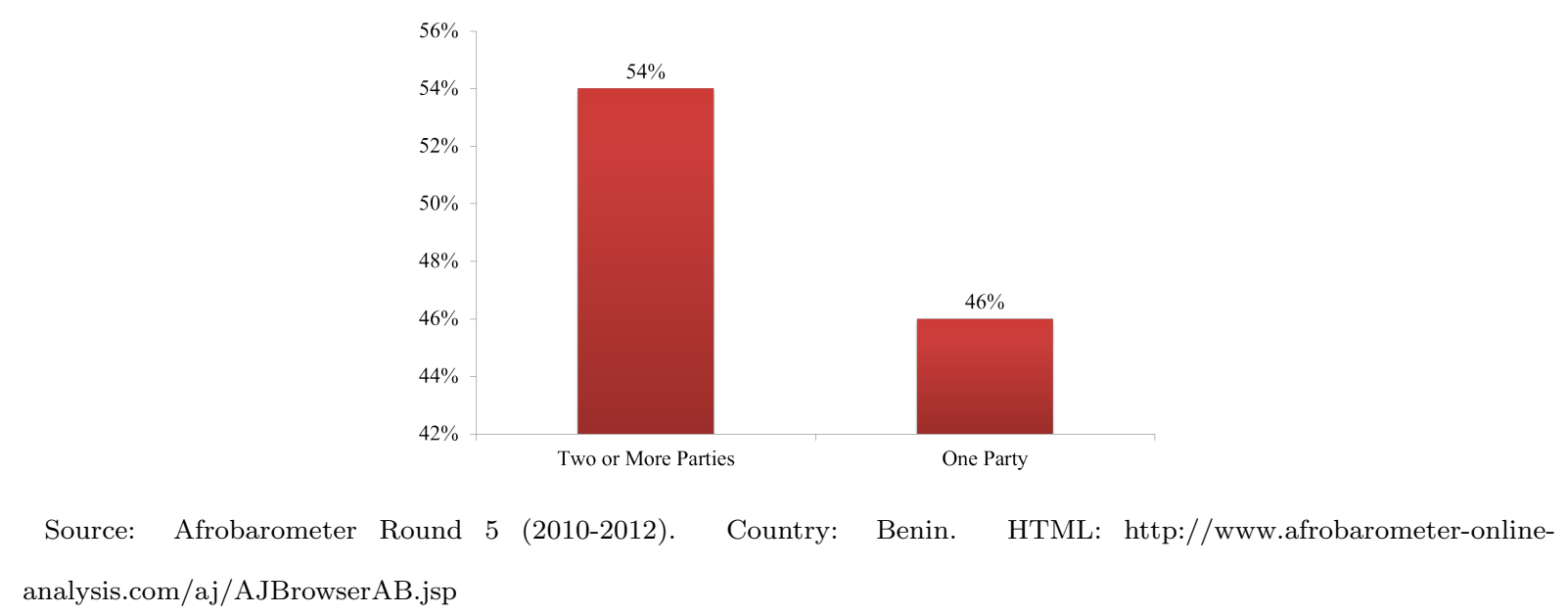

Similar to the previous case, we assume that party $x$ follows a grim-trigger strategy if voters defect. Therefore, to induce cooperation, now party $y$ has to guarantee that the benefits of cooperating are equal or greater than those from defecting but receiving an electoral handout $p_{i}^{x}$ from party $x$. In such scenario we have:

$$
\frac{1}{1-\beta}\left(V_{i}^{y}+p_{i}^{y}\right) \geq V_{i}^{x}+p_{i}^{y}+\frac{\beta}{1-\beta}\left[m\left(V_{i}^{x}+p_{i}^{x}\right)+(1-m)\left(V_{i}^{y}+p_{i}^{y}\right)\right]
$$

Which simplifies to:

$$
p_{i}^{y}-p_{i}^{x} \geq \psi\left(V_{i}^{x}-V_{i}^{y}\right)
$$

Where $\psi=\frac{1-\beta+m \beta}{m \beta}$. In the case of more than one party competing for votes, the difference in the offers from each party has to be greater than the difference in the intrinsic valuation of parties weighted by $\psi$. Comparing (2) to (4) we observe that if $p_{i}^{x}>0$ then the rewards offered by party $y$ to sustain cooperation are higher under competition than when no competition is present. Given $\Phi=\psi$ and the inequality in (4) is binding because parties would prefer to pay the minimum necessary to sustain cooperation, it follows that for the same intrinsic valuations of voter $i$, the bribe offered by party $y$ is higher in (4). Such finding suggests that in the presence of multiple offers from different 
political parties, bribes paid by each party become more expensive. Similarly to the case above, low monitoring leads to prohibitively high prices to be paid as there is a level of monitoring $m^{* *}$ below which $p_{i}^{y}$ goes to $\infty$. When parties are budget constrained and unable to fulfill such prices, then voters might just take the bribe and vote according to their intrinsic preferences.

To summarize, the findings of this section are the following: first, in contexts with no prospects of future interactions and imperfect monitoring by political parties, votechoices will not be driven by the size of the reward obtained. Rather, the expected punishment and the intrinsic valuations of the individual to certain parties will be a crucial determinant of vote-choices. Second, even in infinitely repeated games in which parties follow grim-trigger strategies, low monitoring actually leads to the price to be paid for sustained cooperation to become infinitely high. The situation is aggravated in the presence of competition by other parties which further drive prices up. The latter, combined with the low monitoring capabilities of parties, makes the bribe to be paid again infinitely high for the party and increasing the likelihood that it will not be fulfilled. In addition, the presence of more than one party distributing handouts may explain why parties actually continue doing so even if these actually do not purchase votes: the prisoner's dilemma structure of the game prevents each party from stop giving out handouts in fear of their absence may drive prices sufficiently low as to be purchased by the other party.

\section{Data and Methodology}

\subsection{Estimation Strategy}

Based on the result of (2) in which the inequality constraint binds (parties will pay the least possible), we notice that the vote choice of either party $x$ or party $y$ of voter $i$ in constituency $\alpha_{c}$ hit by some idiosyncratic shock $\epsilon_{i c}$ and individual characteristics $\mathbf{x}_{i c}$ (e.g. degree of partisanship, education, poverty, ethnicity, etc.), can be written as:

$$
\begin{gathered}
V_{i c}^{x}-V_{i c}^{y}=\alpha_{c}+1 / \Phi+\mathbf{x}_{i c}+\epsilon_{i c} \quad \text { if } p_{i c}^{y}=1 \\
\text { Or, } \\
V_{i c}^{x}-V_{i c}^{y}=\alpha_{c}+\mathbf{x}_{i c}+\epsilon_{i c} \quad \text { if } p_{i c}^{y}=0
\end{gathered}
$$

Which can be written as: 


$$
\operatorname{Vote}_{i c}^{y}=\alpha+\beta \cdot p_{i c}+\alpha_{c}+\mathbf{x}_{i c}^{\prime}+e_{i c}
$$

Where $\operatorname{Vote}_{i c}^{y}$ is 1 if voting for party $y$ and 0 otherwise and $p_{i c}$ indicates whether she received an electoral handout from party $y$ and $\alpha_{c}$ are constituency level characteristics. We want to assess the final vote choice relative to the counterfactual where individual is not given a handout:

$$
E\left(\operatorname{vote}_{i c}^{y} \mid p_{i c}^{y}=1\right)-E\left(\operatorname{vote}_{i c}^{y} \mid p_{i c}^{y}=0\right)=\beta
$$

Since we cannot measure the vote choices for the same individual $i$ who was given a handout, we will compare vote choices across $i$ 's and $j$ 's. Therefore, our estimate of the effect of electoral handouts will be based on:

$$
E\left(\operatorname{vote}_{i c}^{p} \mid p_{i c}^{y}=1\right)-E\left(\operatorname{vote}_{j c}^{p} \mid p_{j c}^{y}=0\right)=\hat{\beta}
$$

To avoid concerns of selection, our empirical strategy uses different matching techniques. A concern with matching is utilizing the appropriate variables to predict the likelihood of receiving the treatment. Consequently, there is a need to include a whole set of variables that might influence whether an individual is likely targeted to receive a cash handout, such as the degree of partisanship and income level. For instance, Nichter (2008) and Stokes (2005) find that the level of support or partisanship will influence the odds of being targeted with handout. However, the authors disagree on what degree of partisanship is more likely to be targeted. Stokes (2005) argues that those weakly opposed are most likely to be approached by political machines to ensure their support. Since strong supporters cannot credibly threaten to vote against their preferences, party machines prefer to target those indifferent or "just" opposed. In contrast, Nichter (2008) argues that passive supporters are most likely to be targeted. The expectation is that once a material inducement is offered and accepted, passive supporters would then vote for the party they support. To account for these possibilities, we include a measure of party membership and use both AB surveys from Benin and Kenya as robustness checks which include a explicit measure of partisanship.

In terms of economic variables, it is generally hypothesized that those with less economic resources are likely to be targeted since their votes are cheaper to purchase (Nichter 2008; Dixit and Londregan 1996; Stokes 2005; Brusco et.al 2004; Kramon 2012). We therefore include two measures of income. The first is an objective poverty index based on home ownership, property size (number of rooms), water and electricity services and roofing material. The second is an indicator variable of the level of formal education (none, primary, secondary or higher). Other variables, such as the level of reciprocity 
(Finan and Schechter 2012) are not directly controlled for, but since these would act against the hypothesis of a zero effect for vote-buying, they are less of a concern for our estimates.

Finally, we include a host of socio-demographic covariates in the matching equation, such as the ethnicity, gender and respondent age. In addition to the variables described above, when using the Afrobarometer surveys, we also match on information of whether respondents perceive their vote to be secret, their employment status, opinion of democracy, their subjective perception of poverty, and urban or rural residence. Using the same covariates for matching in both the Benin and Kenya datasets makes the results from both surveys comparable. We estimate equation (5) using exact, nearest, genetic (Diamond and Sekhon 2005) and coarsened exact matching (King et al. 2012). ${ }^{5}$

\subsection{Data Sources}

Our data originates from pre-campaign and post-electoral surveys of the 2011 presidential election in Benin. This election saw three top candidates: Yayi Boni, running as the incumbent candidate; Adrien Houngbedji from the Union Makes the Nation coalition of parties (UN), who also ran in the previous election as the candidate of the Party for Democratic Renewal (PRD); and Abdoulaye Bio Tchane (ABT), an economist and former Director of the Africa Department at the IMF. The 2011 campaign started on February 10 and ended on March 12, 2011. Benin has a presidential system with a two-round electoral system -if no absolute majority $(50 \%+1)$ is achieved in the first round, there is a second vote. In the case of 2011 election, the incumbent (Yayi) was elected in a single round with $53 \%$ of the vote. A particularity of our survey is that it was part of a broader research agenda to evaluate the effect of different campaign strategies - issues based town-hall meetings versus traditional rallies - on voter behavior (Wantchekon 2012). To avoid capturing changes in voting behavior induced by the intervention, we limit the analysis to villages where no intervention occurred (control). Therefore, the data was collected from districts in which the main form of campaigning was rallies, or massive events organized by the candidates in which speeches are delivered and where most cash distribution occurs. These rallies were organized by political figures such as the local mayor, a Member of Parliament, or a local broker.

\footnotetext{
${ }^{5}$ Given the multiplicity of matching techniques available and the different criteria for pairing off observations, it is important for us to show results from different techniques that may achieve better (or worse) balance of the covariates included. According to Ho et al. (2007): "Exact" matching pairs those individuals who received a handout conditional on having the same values on all other covariates. In contrast, "Genetic" matching (Diamond and Sekhon 2005) uses a specific algorithm to "...find a set of weights for each covariate such that a version of optimal balance is achieved after matching" (Ho et al. 2007:12). Finally, Coarsened Exact Matching (King et al. 2012) is implemented to find exact matches within pre-established bounds
} 
The post-electoral survey includes 90 villages with approximately 30 respondents randomly selected such that the sample accounts for $N=2,272$ individuals. The survey captures the electoral outcomes and behavior in the aftermath of the election as well as standard demographic, socioeconomic and partisan information. The main explanatory variable is an indicator for whether the individuals report receiving "money" which implies being offered a handout and accepting it. We consider it a conservative measure of our dependent variable by avoiding potential overstatements of the actual prevalence of vote-buying. However, this measure might downward bias our estimates due to social desirability bias. As we will show, the levels of reticence are low thus suggesting this might be a lesser concern in the Beninese and Kenyan context. We also exclude from the dependent variable individuals reporting receiving calendars and t-shirts during the campaign since these may just reflect propaganda and not attempts to purchase votes.

To cross-validate the results obtained from our survey, we also use Round 5 of the Afrobarometer (AB) in Benin conducted after the 2011 election, which contains a different, yet related, battery of questions on vote-buying. For instance, unlike our own post-electoral survey, AB includes a direct measure of partisanship (not only party membership), subjective measures of poverty, and whether voting is perceived as secret. We try to reconstruct as closely as possible the specification used in our own survey to test the robustness of the findings. Although the Afrobarometer survey has fewer respondents ( $\mathrm{N}=1200)$ it includes a larger number of villages (150) thus covering more electoral districts. Moreover, the Benin Afrobarometer survey allows us to test the sensitivity of the results to a different measure of the dependent variable, as well as account for the effect of receiving cash handouts from multiple candidates.

For further robustness checks, we include Round 5 of the AB from Kenya to crossvalidate the results obtained in Benin. The survey was conducted in 2011 and included a sample size of $N=2,400$ from 44 counties (districts). Unfortunately, the survey was carried out long after the latest national election in 2007. Hence, responses strongly rely on the recall ability of respondents. However, the survey protocol and instruments in the two countries are identical, which facilitates the comparability of the results.

\subsection{Descriptive Statistics}

Table 1 presents the descriptive statistics for the variables included in the analysis. Panel A shows the Afrobarometer (AB) Round 52011 post-electoral survey for Benin. This survey has the advantage of coding whether individuals received "electoral incentives" from more than one party. The coding of a multiplicity of parties will allow us to check the prevalence and effect of such a practice. The key variable is an indicator taking a value of 1 if the respondent was offered an "electoral incentive" and 0 otherwise. We 
have previously mentioned the drawbacks of this wording, yet it is the most commonly used measure of electoral handouts and can be contrasted with our own measures based on having actually "received" rewards. A follow-up question then asks from how many parties or candidates have made offers to the respondent. According to Panel A of Table 1 , around $35 \%$ of the surveyed individuals report being offered "electoral incentives." 6 Of that proportion, $16.8 \%$ received offers from only one party, while $19.8 \%$ received offers from more than one party. This simple statistic shows the prevalence of multiple rewards in the context of the 2011 election. One concern with this variable is that it does not distinguish between money and other gifts in general (e.g. electoral propaganda), therefore possibly overestimating the distribution of cash handouts. Similarly, Round 5 of the Afrobarometer for Kenya shows that around 33.4\% of voters have been offered an electoral incentive (Panel C).

\section{[Insert Table 1 here]}

Panel B reports the statistics for our own 2011 survey, where $29.1 \%$ of individuals report being offered money, while $7 \%$ report having receiving other gifts (not t-shirts or calendars) from a candidate during the campaign. As noted, once we measure directly whether money (as opposed to other gifts) was received from political parties and candidates, we find a slightly smaller but not very different mean in the reported electoral handouts. It is worth noting the similarity in the self-reported prevalence of vote-buying and the rates found in other contexts even after using list-experiments (Gonzalez-Ocanto et.al 2012). Such coincidence might suggest that social desirability bias is a lesser concern in this context. Overall, taken at face value, such statistics would suggest a high prevalence of vote-buying attempts in the 2011 Benin elections.

In terms of vote-choice our own post-electoral survey closely follows the actual vote share of the opposition, but tends to underestimate the preferences for the incumbent (Yayi) when compared to the official results reported in Panel D. In contrast, Round 5 of the Afrobarometer survey in Benin most closely resembles actual voting results. For Kenya, Round 5 of AB captures an estimated vote intention of $2.3 \%$ for KANU, $48 \%$ for ODM (Orange Democratic Movement) and 19.6\% for PNU. In terms of turnout, Benin's AB survey shows an average of $88 \%$ self-reported turnout while in our own survey turnout is around 93\%. In contrast, turnout in the 2007 elections appears to have been lower in Kenya (72\%). Such differences in turnout will help corroborate the robustness of our results in different contexts.

\footnotetext{
${ }^{6}$ Et lors des dernières élections de 2011, combien de fois, est-ce qu'un candidat ou un membre d'un parti politique vous a offert quelque chose, comme des vivres ou un cadeau ou de l'argent, en échange de votre vote?
} 
Respondent characteristics vary in the different surveys. Compared to our own postelectoral survey, the Afrobarometer survey for Benin captures a slightly older sample of voters with a slightly lower proportion of individuals stating that democracy is preferable. However, rates of primary and secondary educational attainment are similar in both survey populations. In contrast, the Kenyan respondents from AB Round 5 are, on average, still older, with higher levels of objective poverty but lower levels of perception of such. Also, around $80 \%$ of Kenyan respondents claim to prefer democracy whereas only $75 \%$ of Beninese voters make the same claim. In terms of education levels, both our own post electoral survey and the $\mathrm{AB}$ Round 5 in Benin show a lower percentage of individuals with formal education in Benin than Kenya. Similarly, there is lower declared partisan affiliation in Benin.

A crucial aspect of this data is whether it permits us to construct a valid counterfactual to the electoral behavior of individuals targeted with cash handouts. We use different matching techniques (exact, nearest, coarsened exact matching and genetic matching) to identify a more appropriate counterfactual group by comparing the voting behavior of individuals from the same constituency who are similar in numerous observable characteristics. The figures below show the distribution of propensity scores, the degree of overlap among treatment and control groups, and the balance in explanatory covariates before and after matching during the 2011 Beninese election. Additional figures showing balance within each of the constituencies are shown in the Appendix.

Figure 3: Covariate Balance 2011 Post-Electoral Survey

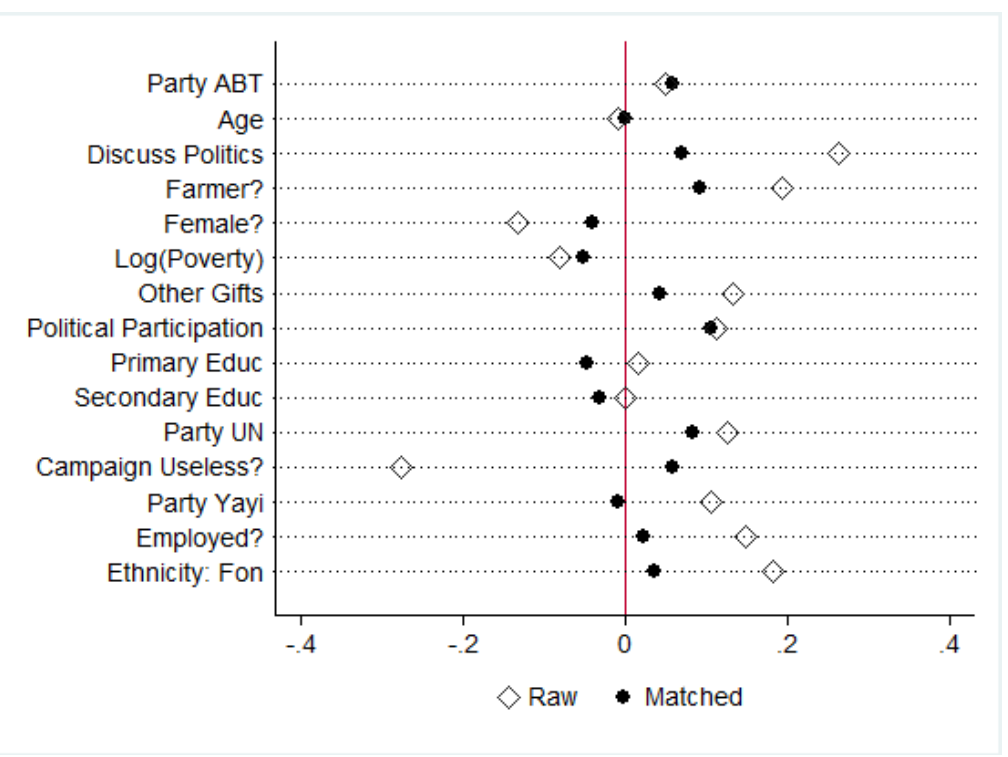


Genetic Matching: Distribution and Overlap
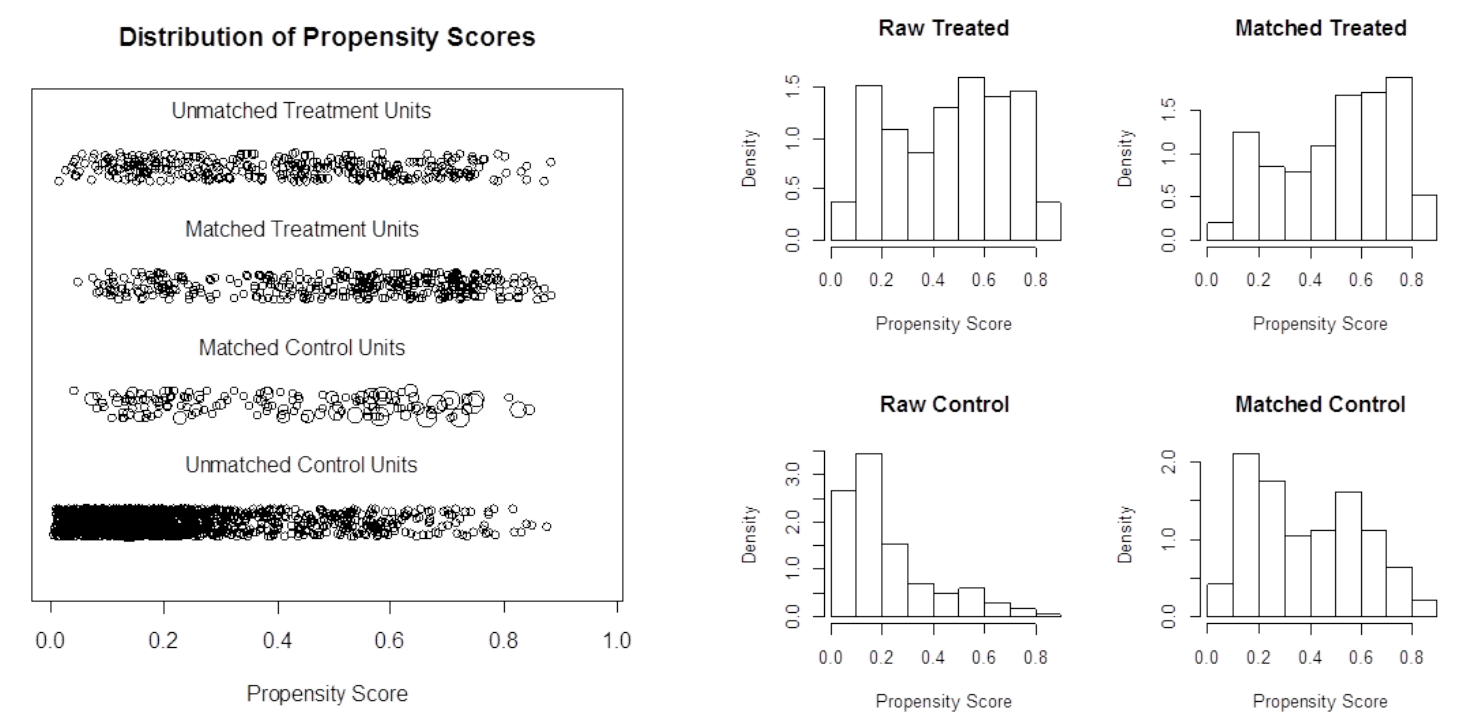

Nearest Matching: Distribution and Overlap

Distribution of Propensity Scores

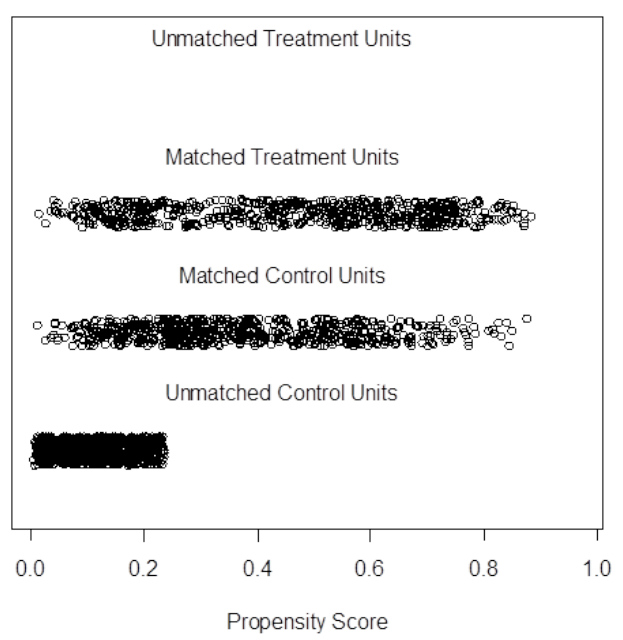

Raw Treated

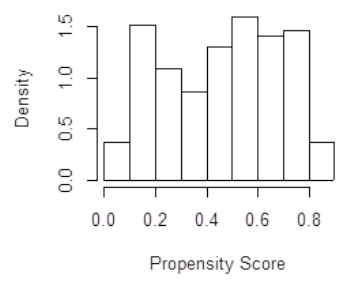

Raw Control

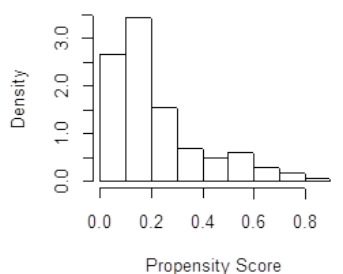

Matched Treated

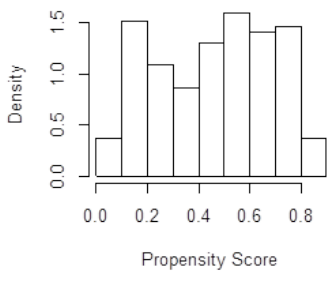

Matched Control




CEM Matching: Distribution and Overlap
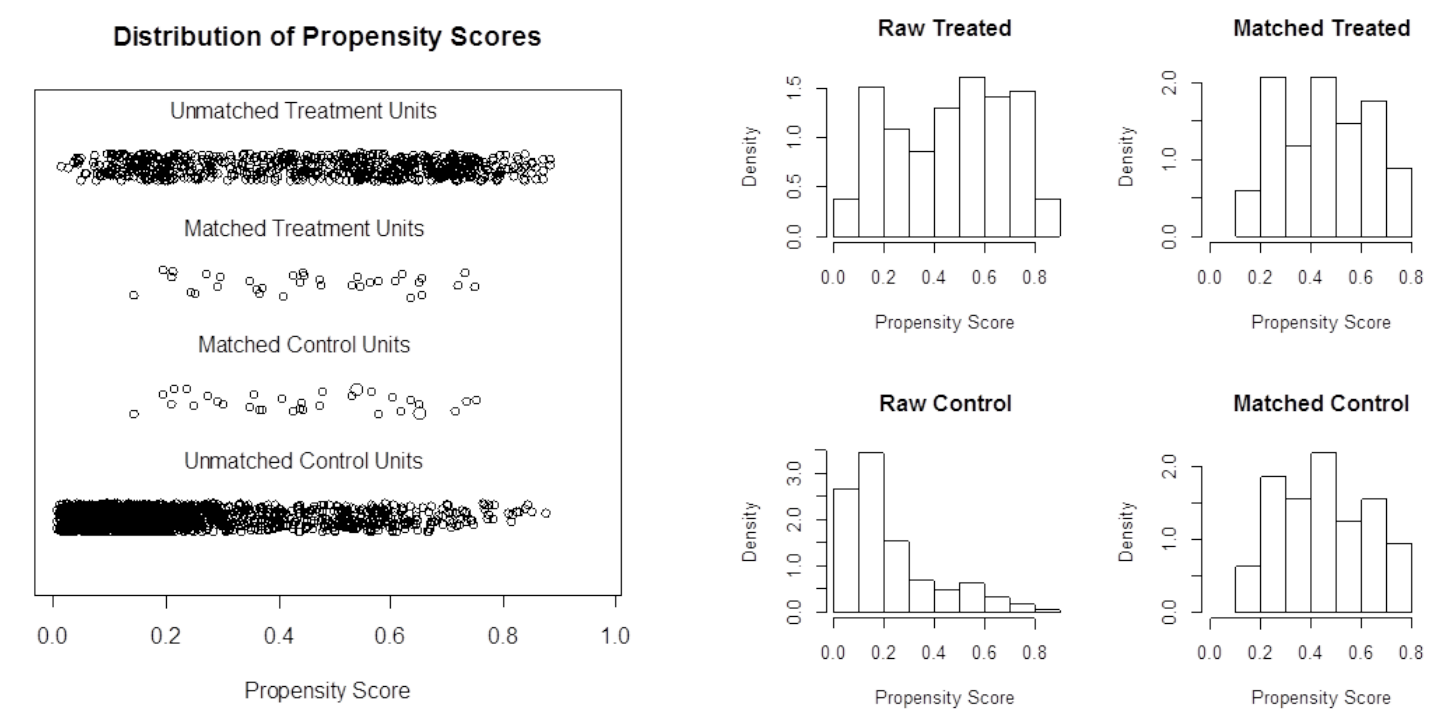

As noted, coarsened exact matching is more restrictive in the number of observations to be matched than genetic matching, probably due to not pre-establishing bounds to match within. However, after matching we can see that the shape and overlap of the propensity score distributions look roughly similar, allowing us more confidence in the estimates obtained. Below, we also show the observed covariate balance after matching according to each method. 
Figure 4: Covariate Balance 2011 Post-Electoral Survey

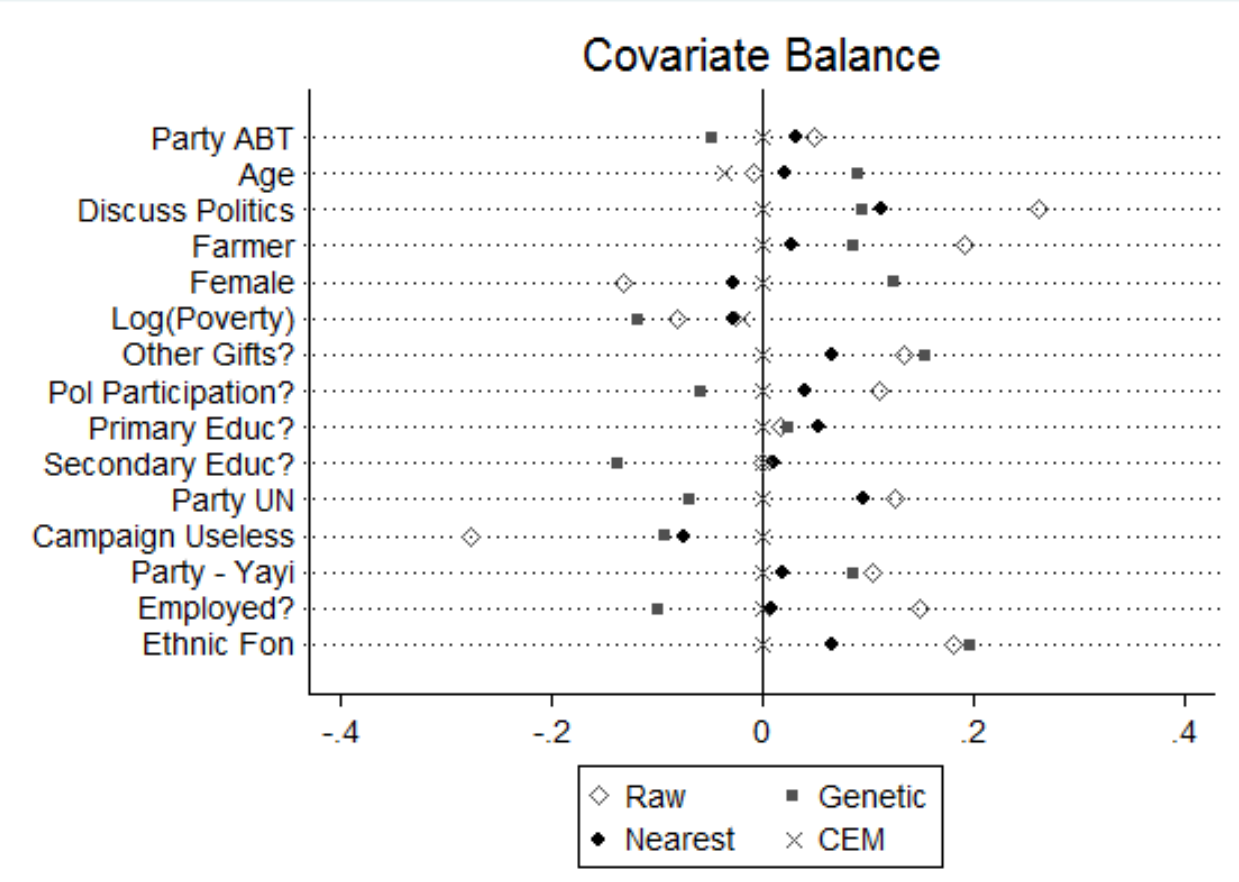

The (pooled) standardized difference in means improves after implementing any matching technique. In particular, differences among the means of treatment and control groups appear to be negligible after implementing CEM matching. In sum, the matching procedure appears to correct important imbalances, and shows that for our outcomes of interest (turnout, vote for Yayi, vote for ABT and vote for UN) there are enough counterfactual units available to match on. In addition, these units exhibit similar distributional shapes and overlap. In the following section, we assess the effect of receiving an electoral handout on vote-choices.

\section{Results}

\subsection{Unmatched Data}

In this section, we start by investigating the effect of electoral handouts on voting behavior. Using similar empirical strategies to previous studies, we rely on unmatched data and do not include time-invariant constituency level characteristics. However, we do incorporate a comprehensive set of control variables to account for a number of alternative explanations, such as those based on socioeconomic conditions, occupational 
choices, democratic preferences and interest in politics or ethnicity. The purpose is to identify whether receiving a cash handout has any effect on the electoral behavior of Beninese voters during the 2011 presidential election. Following Ho. et. al. (2007) we depict graphically the improvement in balance of the explanatory variables when using propensity score matching (gray dots) compared to the raw data (black dots). Using the 2011 Beninese survey we find that while the propensity score is closely to identical in almost every quantile (as shown by the alignment with the 45-degree line), the same is not true when using raw data.

Figure 5: Do We Need Matching?

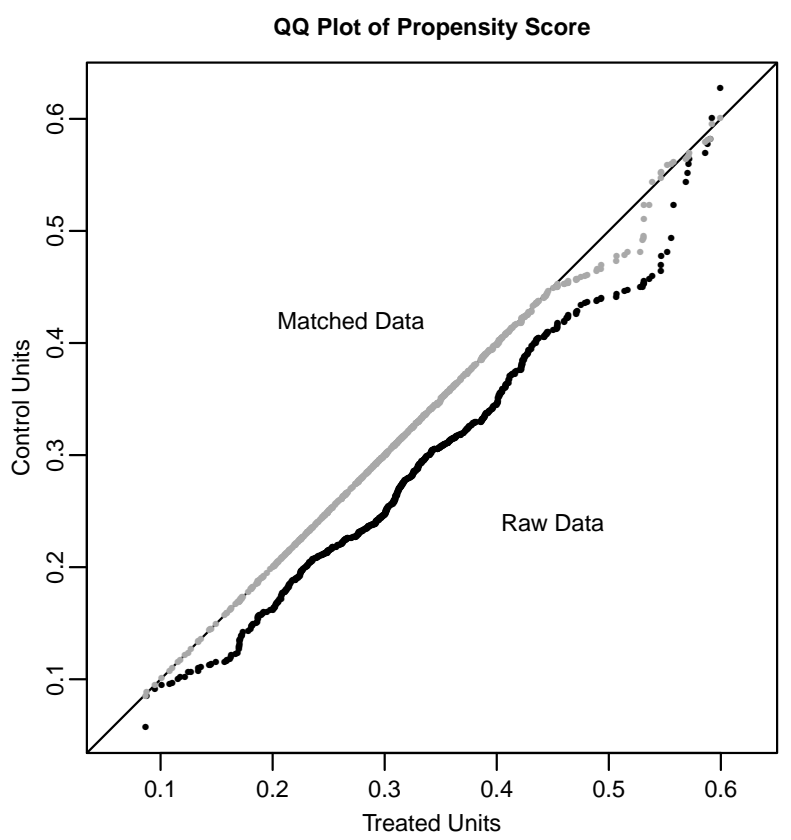

Source: Post-electoral Survey Benin 2011. One-to-one nearest neighbor matching where the propensity score was estimated using the following variables: $\log$ (poverty), Age, Female, Primary Education, Secondary Education, Political participation, Farmer occupation, Campaign useless, Other gifts, Discuss politics outside, partisanship-UN, partisanship-ABT, partisanship-Yayi, Fon ethnicity. R-Code: Ho et. al. 2007.

As shown in Table 5 (Appendix), cash handouts (the first variable) appear to have a statistically significant effect and in the direction hypothesized by the vote-buying literature. Specifically, receiving a cash handout has a positive effect on the likelihood of turning out to vote (column (1)) and in choosing opposition parties such as ABT (column (4)). The effect shown in Table 5 for ABT is positive and significant at the $1 \%$ level, this strong and positive effect for ABT would lead us to conclude the widespread 
use of vote-buying strategies by small opposition parties or those trailing far behind the front-runners during the campaign. Interestingly, the effect of offering a cash handout is negatively related to voting for the incumbent (Yayi). Taken at face value, these results are consistent with other studies arguing that vote-buying has a positive effect on mobilization and in boosting opposition parties' vote-share by undermining incumbency advantage (Vicente 2012).

Although these findings appear encouraging for the vote-buying literature, it is important to corroborate that they are not driven by particularities of our survey. Therefore, we conduct the same analysis but now using Round 5 of Afrobarometer for Benin. Again, in all specifications we include an extensive set of controls as well as measures of partisanship and vote secrecy - which are unavailable when using our own post-electoral survey. One drawback of the Benin AB survey is the reduced number of observations, yet, the inclusion of partisanship measures will allow us to better account for competing explanations. The picture that emerges from Table 6 (Appendix) is largely consistent with the findings in Table 5 that are based on the post-electoral survey. In particular, being offered a cash handout is strongly related to the likelihood of turning out to vote and for choosing, again, opposition parties (in this case UN). In contrast, the coefficient of the vote-share for the incumbent still exhibits a negative sign but no longer lies within conventional levels of significance. Similarly, reported vote choices for the opposition party ABT are positive, but less precisely estimated. Once more, we see how cash handouts appear to play an important role in the electoral behavior of Beninese voters.

However, to establish the external validity of these findings, we use Round 5 of Afrobarometer in Kenya to assess whether the effect of vote-buying is not just restricted to the Beninese election. Therefore, we estimate the same specification used with Beninese surveys to account for similar confounding factors across both cases. Consistent with previous findings, in Table 7 we find that electoral incentives have a positive and significant effect on turnout and on the vote-shares of both the incumbent (PNU) and main opposition party (ODM). According to these results, one would conclude that there exists a positive effect of turnout on mobilization and vote-shares across different countries and surveys. Yet, two sources of potential bias might be driving the results. First, it is important to use matching to weight more heavily observations that were actually treated and not overestimate the effect of the treatment. Second, district-level characteristics may be influencing the observed effect of driving the result and therefore should be included in the estimation. In the next section we introduce such changes to the estimation strategy. 


\subsection{Turnout}

In Figure 6 below we report the matching estimates. The first estimate shows treatment effects using genetic matching while the second and third estimate are obtained using nearest and coarsened exact matching, respectively. In all cases we estimate the Average Treatment Effect for the Treated (ATT) and match on individual characteristics of individuals as specified. We focus on these estimates given our goal of looking at the counterfactual - the vote-choice and turnout of individuals in the absence of treatment(e.g. electoral handouts). The three estimates show that regardless of the matching technique used, the effect of the treatment (cash handouts) on self-reported turnout fails to achieve conventional levels of statistical significance.

Figure 6: ATT

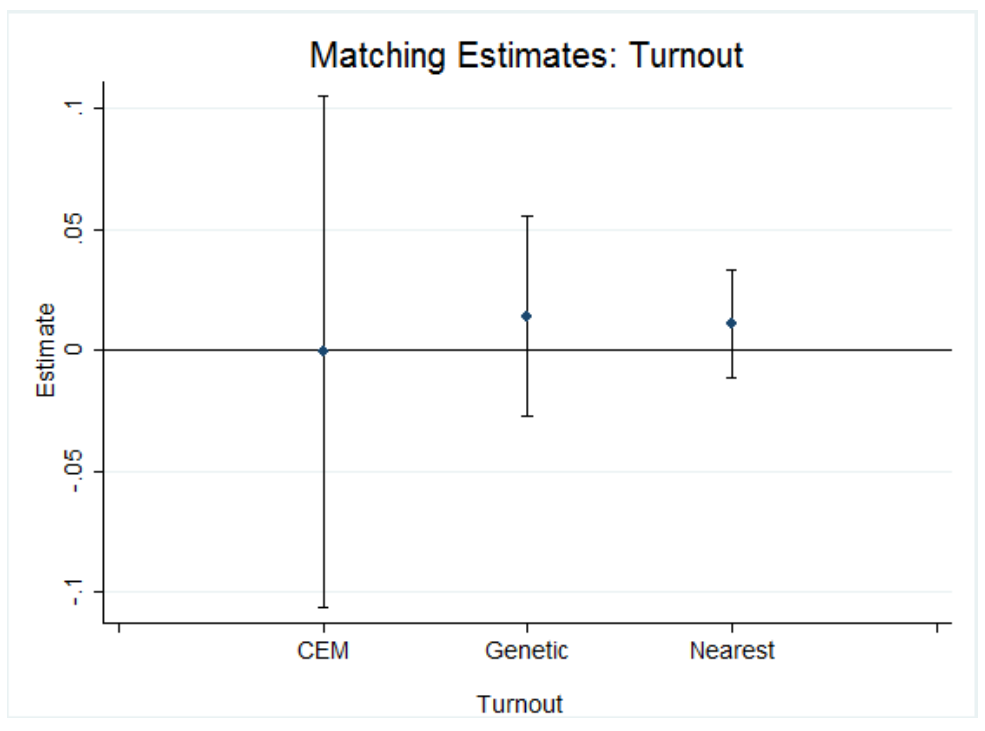

Source: Post-electoral Survey Benin 2011. Propensity score was estimated using the following variables: log(poverty), Age, Female, Primary Education, Secondary Education, Political participation, Farmer occupation, Campaign useless, Other gifts, Discuss politics outside, partisanship-UN, partisanship-ABT, partisanship-Yayi, Fon ethnicity and inclusion of commune level fixed effects.

The last estimate show a slightly larger effect using nearest matching, but still falling below conventional levels of statistical significance and actually suggesting a negative effect of cash handouts on electoral participation. In sum, cash distribution appears to have a positive yet not significant effect on mobilization.

[Insert Table 2 here] 
Since these estimates attribute a negligible effect of cash distribution on turnout, they contrast sharply with other results usually portrayed in the literature (Kramon 2009; Nichter 2008). The main reason for such differences could lie in not accounting for the non-random assignment of electoral handouts as well as comparing individuals from different electoral districts, thus leading to an overestimation of private rewards on mobilization. Therefore, in this case, we show that the use of matched data accounts for the fact that those more likely to receive a handout are also likely to turnout yet due to reasons other than the handout provided.

A key question in the literature is what factors determine whether an individual is offered or receives a cash handout. Based on the probit estimates of the likelihood of receiving an electoral handout (Table 8 in the Appendix), we find results similar to those of previous studies. For instance, higher levels of involvement with political parties make cash handouts more likely in comparison with those with no partisan involvement. The same occurs among individuals who report discussing politics outside their household and are from the Fon ethnic group. Similarly, "traditional" determinants of receiving electoral handouts, such as poverty, shows a positive effect effect on the probability of being targeted (greater values are actually less poor). That is, private rewards are slightly more likely among those who are particularly poor. We can also observe that those given other types of gifts, also report receiving money. This finding suggests that cash handouts are most likely distributed in a bundle with other goods, possibly during mass rallies. Given the large number of rally attendants during Beninese campaigns, it may come as no surprise that cash handouts have no discernible effect on political participation. Finally, an interesting result is that voters who believe that political campaigns are useless are significantly less likely to report receiving a cash handout, thus suggesting they do find it useful. However, these patterns change once we account for constituency characteristics such that only the political discussion, receiving other gifts and political participation have a direct effect on the likelihood of receiving a cash during the campaign.

To compare these findings to those of Afrobarometer, we estimate a similar specification (Table 9). Results contrast with those found in our own post-electoral survey in two ways: first, the AB survey shows a slightly positive effect of education on the likelihood of cash handouts. Second, subjective perceptions of poverty actually exert a negative effect on the likelihood of receiving a cash handout. In addition, although previously we did not account for partisanship, once we do include these variables the results differ with those of the previous literature (Stokes 2005; Nichter 2008). Finally, the only variable that consistently predicts a lower likelihood of electoral handouts is the cash-earning status of the respondent: individuals are consistently less likely to report receiving money for votes if they receive wages. Whether due to a higher level of political involvement of 
people with greater income or to the higher "cost of the vote', this correlation should be further studied.

In sum, our estimates of the impact of cash handouts on turnout suggest a null effect. While other studies have found a positive effect of private rewards on turnout (Nichter 2008; Kramon 2009) we find no evidence that this is the case. Although our results do not capture the extent to which social desirability matters, we do not believe it does significantly for Beninese respondents; other studies in the African context attempting to elicit truthful responses on the prevalence of receiving handouts found that social desirability mattered little (Kramon 2011). Moreover, we find similar estimates of votebuying in studies that do account for such potential biases (Gonzales-Ocanto et al. 2012). Hence, the next pressing question is, would vote-choices be at all different in the absence of cash handouts? In the next section we analyze whether cash distribution in the 2011 Beninese campaign had any effect on vote-choices.

\subsection{Vote Choices}

In Figures 7 and 8 we present the matching estimates of cash handouts on vote choices using genetic and nearest neighbor matching, respectively.

Figure 7: ATT

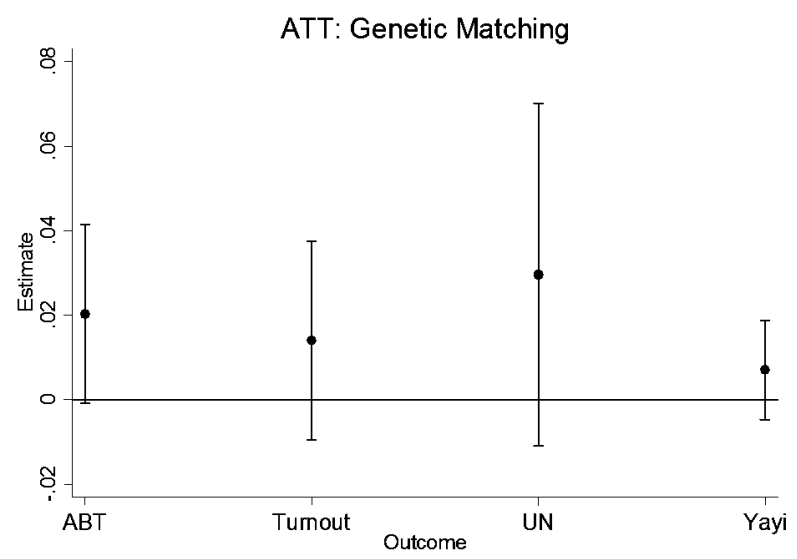

Source: Post-electoral Survey Benin 2011. Propensity score was estimated using the following variables: log(poverty), Age, Female, Primary Education, Secondary Education, Political participation, Farmer occupation, Campaign useless, Other gifts, Discuss politics outside, partisanship-UN, partisanship-ABT, partisanship-Yayi, Fon ethnicity and inclusion of commune level fixed effects.

Results in Figure 7 suggest that the effect of receiving an electoral handout does not affect the likelihood of voting for the incumbent (Yayi) or the opposition candidates 
(ABT or UN). That is, in all cases, estimates reveal that the effect of receiving an electoral reward is not statistically different from zero.

Figure 8: ATT

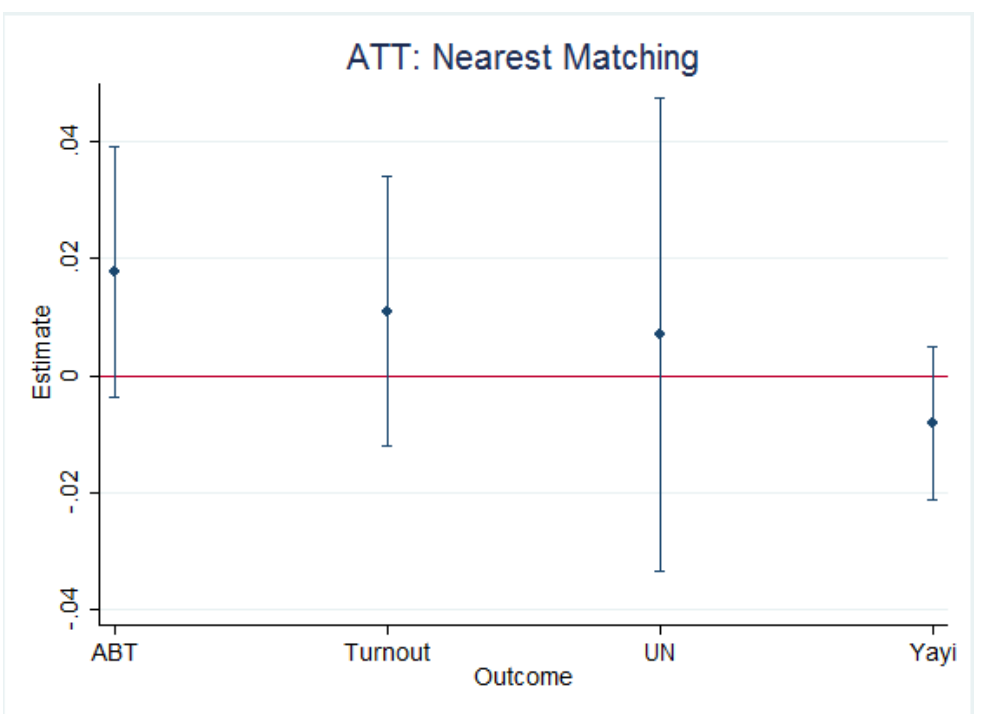

Source: Post-electoral Survey Benin 2011. Propensity score was estimated using the following variables: $\log ($ poverty), Age, Female, Primary Education, Secondary Education, Political participation, Farmer occupation, Campaign useless, Other gifts, Discuss politics outside, partisanship-UN, partisanship-ABT, partisanship-Yayi, Fon ethnicity and inclusion of commune level fixed effects.

Using a different matching technique in Figure 8 (nearest neighbor matching) the effect of money now appears to be outright negative in the case of the incumbent (Yayi, columns (1) and (2)) yet far from achieving conventional levels of statistical significance. We interpret these estimates as showing a lack of statistical association between electoral handouts and vote-choices. In Table 3 we present the matching estimates of cash handouts on vote choices. Panel A presents the estimates based on Genetic Matching, while Panels $\mathrm{B}$ and $\mathrm{C}$ show the results using Nearest Neighbor and Coarsened Exact Matching.

\section{[Insert Table 3 here]}

These results sharply contrast with the estimates using unmatched data as shown in columns (2) through (4) of Table 5, thus suggesting that the use of matching techniques actual yields different estimates in comparison to other approaches. One limitation of our data is that we are not able to capture the identity of the distributing party, hence we test whether any candidate is benefited from the distribution of handouts. 
Interestingly, we observe a similar pattern using the Afrobarometer data: a strong positive effect of electoral handouts on turnout, and a positive and slightly significant (10\% level) effect for UN vote choices with unmatched data (Table 6). However, as shown in columns (1) through (4) of Table (10) this effect disappears once we use matching techniques such that the difference between those who received a reward and those who did not is not significantly different from zero. The only exception is column (1), where the difference appears to be positive and statistically different from zero. However, this estimate seems to be an isolated finding using genetic matching in comparison to other matching techniques, hence we should interpret this result with caution. Moreover, as noted earlier, genetic matching tended to achieve poor covariate balance compared to exact matching. Finally, CEM matching greatly limited the number of observations to be used, and is therefore unable to provide an estimate for the case of ABT, given his limited number of supporters.

Given the observed differences in the inferences made from parametric approaches to those using matching, it is important to determine whether differences on unobservables would lead us to observe a significant result and change our inference. To do so, we conduct a sensitivity analysis following the method proposed in Rosenbaum (2002) and implemented by Becker and Caliendo (2007). Specifically we evaluate the degree at which negative selection on unobservables might change the results examined here.

We perform this test using the 2011 Beninese post-electoral survey and we first match on the characteristics described above using one-to-one matching and then we examine how much greater have the odds have be to be selected into the treatment (given the same set of covariates) and render the treatment smaller than it actually is. Since our argument here is concerned with the null or no positive effect of electoral handouts, we focus on the case of negative selection. That is, the case in which those individuals most likely to receive a handout would also tend to have lower turnout and certain vote-choices even in the absence of the handout given they have the same characteristics as the individuals in the comparison group. 
Figure 9: Sensitivity Analysis



Source: Post-electoral Survey Benin 2011. Propensity score was estimated using the following variables: $\log ($ poverty), Age, Female, Primary Education, Secondary Education, Political participation, Farmer occupation, Campaign useless, Other gifts, Discuss politics outside, partisanship-UN, partisanship-ABT, partisanship-Yayi, Fon ethnicity and inclusion of commune level fixed effects.

We focus on our four binary outcomes: turnout, vote Yayi, UN or ABT. Following Keele (2010: 13) we examine values of gamma ranging between 1 and 2, which are deemed appropriate for the social sciences. The figure in the top left corner shows that in order to find a positive significant effect on the turnout rate (at the $1 \%$ level), the selection into getting a handout (given the same covariate) needs to be around twice the odds of being selected. The same is true for the case of voting for Yayi. However, when looking at vote-choices for UN and ABT, the opposition parties, our inference of a null effect would change at values of $\Gamma>1.2$ and $\Gamma>1.5$, respectively. Therefore, we should interpret the result on the opposition vote choices with caution given these are sensitive to deviations form the unconfoundedness assumption.

\subsection{Cross-Validation: Kenya}

One concern with our results is context-specificity, as they could be driven by features unique to the 2011 Beninese election. To alleviate such concerns, we estimate the same model using data from Round 5 of the AB survey in Kenya. This survey captures the electoral behavior and opinion of Kenyans during the 2007 general election. In this highly competitive election, the incumbent Kibaki from the Party of National Unity was closely 
followed by Odinga (Orange Democracy Movement) and Musyoka. The incumbent's victory and the close vote resulted in widespread post-election violence with a death toll of around 1,000 people. The violence finally ceased in 2008 and Odinga went on to serve as Prime Minister in the subsequent government. As noted earlier, the conditions surrounding these elections are quite different from those prevailing in Benin; therefore it would be a good test case of our findings in the previous section.

In Table 4 below, we show the matching estimates using the same variables as in the case of Benin, but now using the Kenyan data.

[Insert Table 4 here]

As shown in Table 4, the effect of cash handouts does not have any effect on the electoral behavior of Kenyan voters. Rather, it appears that electoral behavior is driven by factors other than the sheer distribution of cash handouts. For example, as explored theoretically, the low level of monitoring by political parties is a contributing factor to the null effect observed here.

\subsection{Single versus Multiple Offers}

Based on the null result we observe, our next concern is to provide an explanation of why this is the case. Therefore we look at the multiple sources of reward distribution reported in the Afrobarometer survey. The situation has been labeled as "empirically unusual" (Stokes 2005: 324; Nichter 2008: 31), but is it? Finan and Schechter (2012) provide some evidence of more than one party engaging in material rewards, yet it is unclear from their data how receipt of gifts from more than one candidate affects electoral behavior. In the Afrobarometer data, more than one party appears to target the same constituency, thus making enforcement even harder and further weakening the transactional aspect of votebuying. Moreover, bidding wars may allow voters to act strategically and obtain even higher rewards but still vote with their conscience as we see in the theoretical section. 
Figure 10: ATT

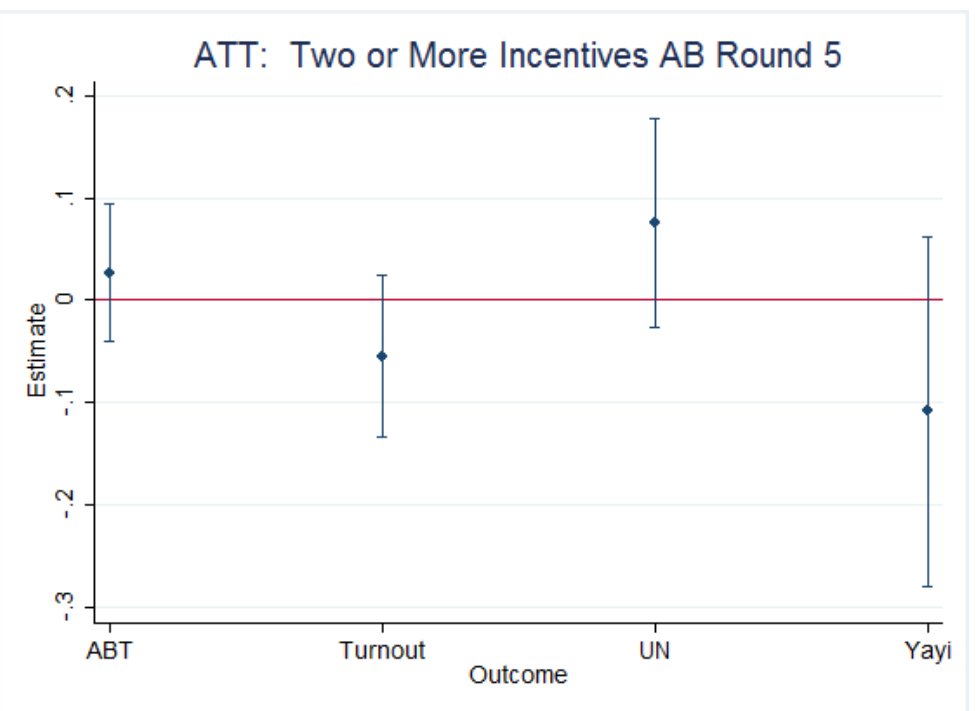

Source: Afrobarometer Survey Benin 2012. Propensity score was estimated using the following variables: poverty (objective), poverty (subjective), No formal Education, Secret vote, Party - Yayi, Party - ABT, Party - UN, Urban, Cash Income, No Party Preference, Female, Age, Primary Educ, Secondary Educ, Opinion Democracy, and inclusion of commune level fixed effects.

Only the Afrobarometer data for Benin contains information on multiple offers, therefore we focus on these in Table 11 in the Appendix. First, as shown in figure 9, receiving an offer from more than one party compared to only receiving one has no effect on turnout and electoral choices of individuals. However, it is important to evaluate if receiving one offer compared to no-offer at all would have a positive effect. As shown in Figure 10, although all point estimates are greater than zero, confidence intervals still include zero making it less likely to rule out a null effect. 
Figure 11: ATT

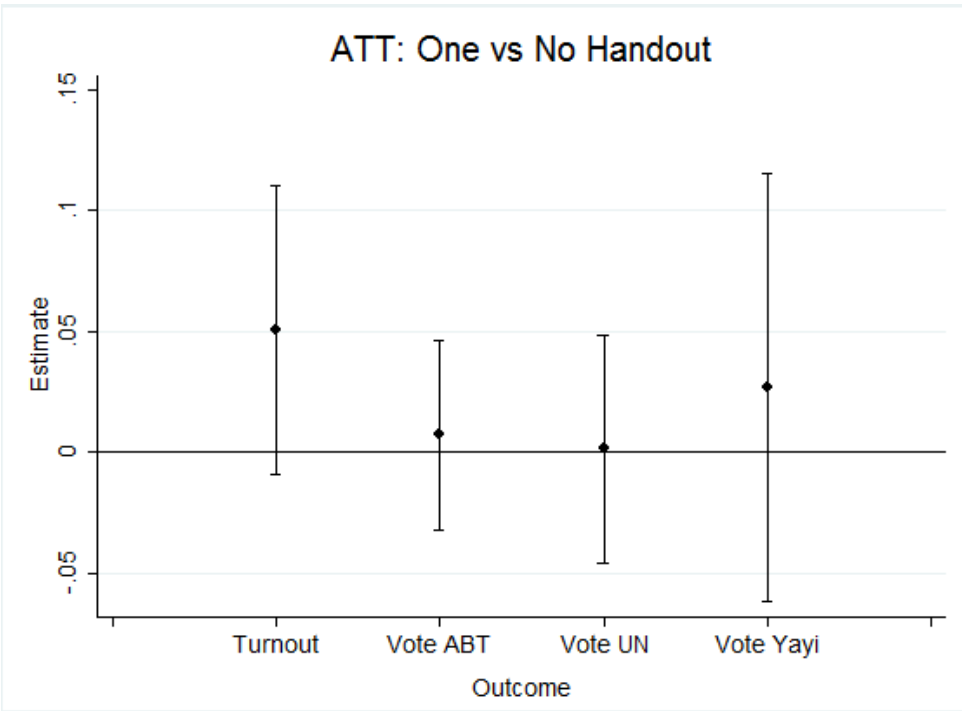

Source: Afrobarometer Survey Benin 2012. Propensity score was estimated using the following variables: poverty (objective), poverty (subjective), No formal Education, Secret vote, Party - Yayi, Party - ABT, Party - UN, Urban, Cash Income, No Party Preference, Female, Age, Primary Educ, Secondary Educ, Opinion Democracy, and inclusion of commune level fixed effects.

Similarly, in Table 10 we observe that electoral incentives from either one or two parties is not associated with any visible difference in electoral behavior either. The same is true for the individuals who received multiple offers of electoral handouts when using Genetic Matching (Table 10, Panel A). However, when looking at the same estimates using exact matching, results show a strong and positive effect on turnout and vote for ABT in the case of single offers. In contrast, those who received two offers or more appear to significantly against voting for Yayi and benefiting UN as a candidate. A potential source of these differences is the different profiles exhibited by those who receive an offer from a single party with those who received more than one offer. Those with only one offer are more likely targeted if poorer (even subjectively) although it has less of an impact whether they are wage earners or not. Hence, this profile more closely fits that of likely targets documented in the vote-buying literature. In contrast, those receiving offers from more than one party are not particularly poorer (either subjectively or objectively), are more educated and only exhibit a preference for the opposition party UN. Hence, this group does not quite match the profile of typical targeted individuals. Although the number of offers does not appear to have much of an impact on electoral behavior, the positive differences and z-scores of Panel B Table 11 are the closest to a positive result for an effect of electoral handouts on political behavior. In addition, given those who were 
targeted once could have had a higher level of monitoring than those who were offered twice, this could explain the differences in the result. This suggests that the widespread indiscriminate nature of cash distribution in sub-Saharan Africa might weaken the votebuying transaction, but that targeted individual handouts might still be relevant under different circumstances.

\section{Conclusion}

In this paper we use evidence from the 2011 Beninese presidential election to investigate whether cash rewards affect affect voting behavior. We find that electoral handouts have no effect on the vote-choice and turnout. Using Afrobarometer data from Benin and Kenya we find that the results are robust to different matching techniques, electoral district fixed effects and an array of different individual characteristics. We argue that this could be due to the multiplicity of offers, given the fact that "multiple targeting" involved around $55 \%$ of those who received gifts. Similarly, the theoretical framework suggests how monitoring may have had a high impact on the completeness of the transaction of cash for votes. Finally, we show that constituency-level variables may play a decisive role in shaping voting behavior.

We find some evidence for the external validity of our findings by using Afrobarometer data from Kenya. This suggests that our results are not driven by particularities of the Beninese case but might in fact be valid across sub-Saharan Africa. Indeed, anecdotal evidence suggests that around the world, very much like in Benin, electoral rewards tend to be distributed during large political rallies which may limit the effectiveness of cashdistribution. This in fact may lead to different results in Latin America, since party machines play a bigger role in targeting voters for electoral handouts. Future research on the topic will further isolate the effect of different components of clientelist redistribution. More specifically, since clientelist redistribution in the form of cash, patronage and local public goods are simultaneously offered to voters in a given district, we need to estimate the relative contribution of each component to voting behavior. The current literature tends to attribute to cash distribution alone what may have been in fact the combined effect of handouts, patronage, and the targeted delivery of public goods. 


\section{Bibliography}

Acemoglu, Daron, Simon Johnson, James A. Robinson, and Pierre Yared. 2008. "Income and Democracy" American Economic Review, 98(3): 808-42.

Angrist, Joshua D., and Jorn-Steffen Pischke. 2008. Mostly harmless econometrics: An empiricist's companion. Princeton University Press.

Ansolabehere, Stephen and James M. Snyder. 2006. "Party Control of State Government and the Distribution of Public Expenditures." Scandinavian Journal of Economics 108(4):547-569.

Banegas, R. 2002. La Democratie a pas de Cameleon. Editions Karthala.

Banerjee, A. et al. 2011. "Do Informed Voters Make Better Choices? Experimental Evidence from Urban India." Mimeo.

Berry, Christopher R., Barry C. Burden and William G. Howell. 2010. "The president and the distribution of federal spending." American Political Science Review 104(4):783-799.

Blaydes, Lisa. 2006. "Who Votes in Authoritarian Elections and Why? Determinants of Voter Turnout in Contemporary Egypt." Prepared for delivery at the 2006 Annual Meeting of the American Political Science Association, August 31-September 3 Philadelphia, PA.

Brusco, Valerie, Marcelo Nazareno, and Susan C. Stokes. 2004. "Vote buying in Argentina." Latin American Research Review: 66-88.

Calvo, Ernesto and Victoria Murillo. 2004. "Who Delivers? Partisan Clientelism in the Argentina Electoral Market". American Journal of Political Science 48(4).

Cox, Gary W. and Matthew D. McCubbins. 1986. "Electoral politics as a redistributive game." Journal of Politics: 370-89.

Dahlberg, Matz and Eva Johansson. 2004. "On the vote-purchasing behavior of incumbent governments." American Political Science Review 96(01):27-40.

Dekel, Eddie, Matthew O. Jackson, and Asher Wolinsky. 2008. "Vote buying: General elections." Journal of Political Economy 116(2): 351-380.

Denemark, David. 2000. "Partisan Pork Barrel in Parliamentary Systems: Australian Constituency-Level Grants." The Journal of Politics 62(3):896-915. 
Diamond, A. and Sekhon, J. 2005. "Genetic Matching for Estimating Causal Effects: A New Method of Achieving Balance in Observational Studies." http://jsekhon.fas.harvard.edu/

Dixit, Avinash and John Londregan. 1996. "The Determinants of Success in Special Interests in Redistributive Politics" Journal of Politics. 58(4): 1132-55.

Finan, Federico and Laura Shechter. 2012. Vote Buying and Reciprocity. Econometrica, 80(2): 863-882.

Galdo, Jose. 2008. "Treatment Effects for Profiling Unemployment Insurance Programs: Semiparametric Estimation of Matching Models with Fixed Effects" Mimeo, Carleton University.

Gonzalez-Ocantos, E., C.K. de Jonge, C. Melendez, J.Osorio, and D.W. Nickerson. 2012. "Vote buying and social desirability bias: Experimental evidence from Nicaragua." American Journal of Political Science, 56(1): 202-217.

Herron, Michael C. and Bretta A. Theodos. 2004. "Government redistribution in the shadow of legislative elections: A study of the Illinois member initiative grants program." Legislative Studies Quarterly 29(2):287-312.

Ho, Daniel E., et al. 2007. "Matching as nonparametric preprocessing for reducing model dependence in parametric causal inference." Political analysis 15(3): 199236.

Horiuchi, Yusaku and Seungjoo Lee. 2008. "The Presidency, Regionalism, and Distributive Politics in South Korea." Comparative Political Studies 41(6):861-882.

Iacus, Stefano M., Gary King, and Giuseppe Porro. 2012. "Causal inference without balance checking: Coarsened exact matching." Political analysis 20(1): 1-24.

Keefer, Philip, and Razvan Vlaicu (2008), Democracy, Credibility, and Clientelism. Journal of Law, Economics, and Organization 24 (2): 371.

Kramon, Eric. 2009. "Vote-buying and Political Behavior: Estimating and Explaining Vote-Buying's Effect on Turnout in Kenya." Afrobarometer, Working Paper No. 114.

Kram, Eric. 2011. "Why Do Politicians Buy Votes When The Ballot Is Secret? Theory And Experimental Evidence From Kenya" Mimeo.

Kramon, Eric. 2010. "Why Do Politicians Distribute Gifts During Campaigns? Survey Experimental Evidence from Kenya." APSA 2010 Annual Meeting Paper. Available at SSRN: http://ssrn.com/abstract $=1644093$ 
Kramon, Eric. 2012. "Vote Buying or Costly Signaling? Cash Handouts and Political Credibility in Kenya" Mimeo Dissertation Paper.

Lehoucq, Fabrice. 2007. "When Does a Market for Votes Emerge?", in F.C. Schaffer (ed.), Elections for sale: The causes and consequences of vote buying. London: Lynne Rienner.

Levine, D. I., and G. Painter. 2003. "The schooling costs of teenage out-of-wedlock childbearing: analysis with a within-school propensity-score-matching estimator." Review of Economics and Statistics, 85(4), 884-900.

Levitt, Steven D. and James M. Snyder Jr. 1997. "The Impact of Federal Spending on House Election Outcomes." Journal of Political Economy 105(1):30.

Nichter, Simeon. 2008. "Vote buying or Turnout Buying? Machine Politics and the Secret Ballot" American Political Science Review 102(1): 19-31.

Robinson, James A. and Thierry Verdier. 2003. "The Political Economy of Clientelism." SSRN Working Paper Series. Rochester, New York.

Nugent, P. 2007. "Banknotes and symbolic capital". In E. G. Basedau, M. and A. Mehler (eds.), Votes, money and violence: political parties and elections in SubSaharan Africa. Scottsville, South Africa: University of KwaZulu Natal Press.

Schaffer, F.C. 2002. "Might Cleaning Up Elections Keep People Away from the Polls? Historical and Comparative Perspectives" International Political Science Review 23,1 (January): 69-84.

Schaffer, F. C. and A. Schedler 2007. "What is vote buying? The limits of the market model". In F. C. Schaffer (ed.), Elections for Sale: The Causes and Consequences of Vote Buying. London: Lynne Rienner Publishers.

Stokes, Susan C. 2005. "Perverse Accountability: A Formal Model of Machine Politics with Evidence from Argentina" American Political Science Review 99:315-325.

Stokes, Susan C. 2007, "Political Clientelism", in C. Boix and S.C. Stokes (eds.) The Oxford Handbook of Comparative Politics. Oxford: Oxford University Press.

Stokes, Susan. C., T. Dunning, M. Nazareno, and V. Brusco. 2012. "Brokers, voters, and clientelism". Unpublished manuscript, Yale University and Universidad Nacional de Cordoba. 
Tucker, Joshua Aaron, et al. 2006. Regional Economic Voting: Russia, Poland, Hungary, Slovakia, and the Czech Republic, 1990-1999. Cambridge: Cambridge University Press.

Van de Walle, Nicolas. 2003. "Meet the New Boss, Same as the Old Boss? The Evolution of Political Clientelism in Africa." Center for Global Development.

Vicente, Pedro C. 2012. "Is vote buying effective? Evidence from a field experiment in West Africa." Unpublished Manuscript.

Vicente, Pedro C. and Leonard Wantchekon. 2009. "Clientelism and Vote Buying: Lessons from Field Experiments in African Elections" Oxford Review of Economic Policy, 25(2):292-305.

Wantchekon, Leonard. 2012. "How Does Policy Deliberation Affect Voting Behavior? Evidence from a Campaign Experiment in Benin." Working Paper, Princeton University.

Wantchekon, Leonard. 2003. "Clientelism and Voting Behavior: Evidence from a Field Experiment in Benin". World Politics, 55(3): 399-422. 


\section{Appendix}

Table 1: Summary Statistics

\begin{tabular}{lccc}
\hline \multicolumn{1}{c}{ Variable } & Mean & Std. Dev. & N \\
\hline \multicolumn{1}{c}{ Panel A - 2011 Benin } & Afrobarometer & \\
\hline Vote is secret? & 0.911 & 0.285 & 1192 \\
Offer by one party? & 0.169 & 0.375 & 1198 \\
Offer two or more? & 0.198 & 0.399 & 1198 \\
Electoral "Incentive"? & 0.366 & 0.482 & 1199 \\
Urban? & 0.44 & 0.497 & 1200 \\
Age & 38.082 & 14.526 & 1189 \\
Voted in 2011? & 0.883 & 0.321 & 1200 \\
Female? & 0.5 & 0.5 & 1200 \\
Poverty (objective) & 7.036 & 2.251 & 1200 \\
Poverty (subjective) & 5.785 & 3.735 & 1198 \\
Source cash income? & 0.184 & 0.388 & 1200 \\
Prefer democracy? & 0.758 & 0.428 & 1194 \\
No partisan preference? & 0.618 & 0.486 & 1200 \\
Prefer FCBE (Yayi)? & 0.273 & 0.446 & 1191 \\
Prefer UN? & 0.076 & 0.266 & 1191 \\
Prefer ABT? & 0.02 & 0.141 & 1191 \\
Voted Yayi? & 0.195 & 0.396 & 2272 \\
Voted UN? & 0.469 & 0.499 & 1119 \\
Voted ABT? & 0.105 & 0.307 & 1119 \\
No education? & 0.048 & 0.214 & 1119 \\
Primary? & 0.409 & 0.492 & 1199 \\
Secondary? & 0.236 & 0.425 & 1199 \\
\hline \multicolumn{1}{c}{ Panel B - 2011 Own Post-Electoral } & \\
\hline Received Money? & 0.291 & 0.454 & 2272 \\
Political Participation? & 0.221 & 0.415 & 2272 \\
Party - UN & 0.032 & 0.175 & 2272 \\
Party - ABT & 0.075 & 2272 \\
Party - FCBE & 0.196 & 2272 \\
Age & 0.435 & 1199 \\
\hline
\end{tabular}

Continued on next page 
Table 1 - Continued from previous page

\begin{tabular}{lccc}
\hline \multicolumn{1}{c}{ Variable } & Mean & Std. Dev. & N \\
\hline Employed? & 0.647 & 0.478 & 2272 \\
Campaign Useless? & 0.114 & 0.317 & 2272 \\
Other Gifts? & 0.07 & 0.255 & 2272 \\
Voted? & 0.939 & 0.24 & 2272 \\
Voted Yayi? & 0.235 & 0.424 & 2272 \\
Voted ABT? & 0.059 & 0.236 & 2272 \\
Voted UN? & 0.326 & 0.469 & 2272 \\
Farmer? & 0.548 & 0.498 & 2272 \\
Female? & 0.441 & 0.497 & 2272 \\
Discuss Politics? & 0.504 & 0.5 & 2272 \\
Log(Poverty) & 0.766 & 0.808 & 2272 \\
Ethnicity Fon & 0.419 & 0.494 & 2272 \\
\hline
\end{tabular}

Panel C - 2011 Afrobarometer Kenya

\begin{tabular}{lccc}
\hline Vote is secret? & 0.883 & 0.322 & 2242 \\
Urban? & 0.383 & 0.486 & 2399 \\
Electoral "Incentive"? & 0.334 & 0.472 & 2360 \\
Age & 40.666 & 69.352 & 2395 \\
Voted in 2007 & 0.726 & 0.446 & 2394 \\
Female & 0.5 & 0.5 & 2399 \\
Poverty (objective) & 6.286 & 1.819 & 2308 \\
Poverty (subjective) & 3.915 & 3.467 & 2391 \\
Source cash income? & 0.449 & 0.497 & 2392 \\
Employed? & 0.449 & 0.497 & 2392 \\
No partisan & 0.423 & 0.494 & 2399 \\
Prefer ODM? & 0.299 & 0.458 & 2364 \\
Prefer PNU? & 0.158 & 0.365 & 2364 \\
Prefer KANU? & 0.016 & 0.126 & 2364 \\
Voted KANU? & 0.023 & 0.151 & 1939 \\
Voted ODM? & 0.48 & 0.5 & 1939 \\
Voted PNU? & 0.196 & 0.397 & 1939 \\
Prefer Democracy & 0.804 & 0.397 & 2190 \\
No Education & 0.062 & 0.241 & 2392 \\
Primary & 0.355 & 0.479 & 2392 \\
Secondary & 0.401 & 0.49 & 2392 \\
\hline
\end{tabular}


Table 1 - Continued from previous page

\begin{tabular}{|c|c|c|c|}
\hline Variable & Mean & Std. Dev. & $\mathbf{N}$ \\
\hline \multicolumn{4}{|c|}{ Panel D - 2011 Benin Official Village Results } \\
\hline Turnout & 85.478 & 13.557 & 90 \\
\hline$\%$ Votes Yayi & 55.691 & 22.657 & 90 \\
\hline$\%$ Votes ABT & 6.935 & 12.847 & 90 \\
\hline$\%$ Votes UN & 29.751 & 25.576 & 90 \\
\hline$\%$ Votes Opposition (ABT and UN) & 36.686 & 24.365 & 90 \\
\hline
\end{tabular}

*Questions with "?" indicate a Yes=1 answer. 
Figure 12: Covariate Balance within Constituency: Poverty

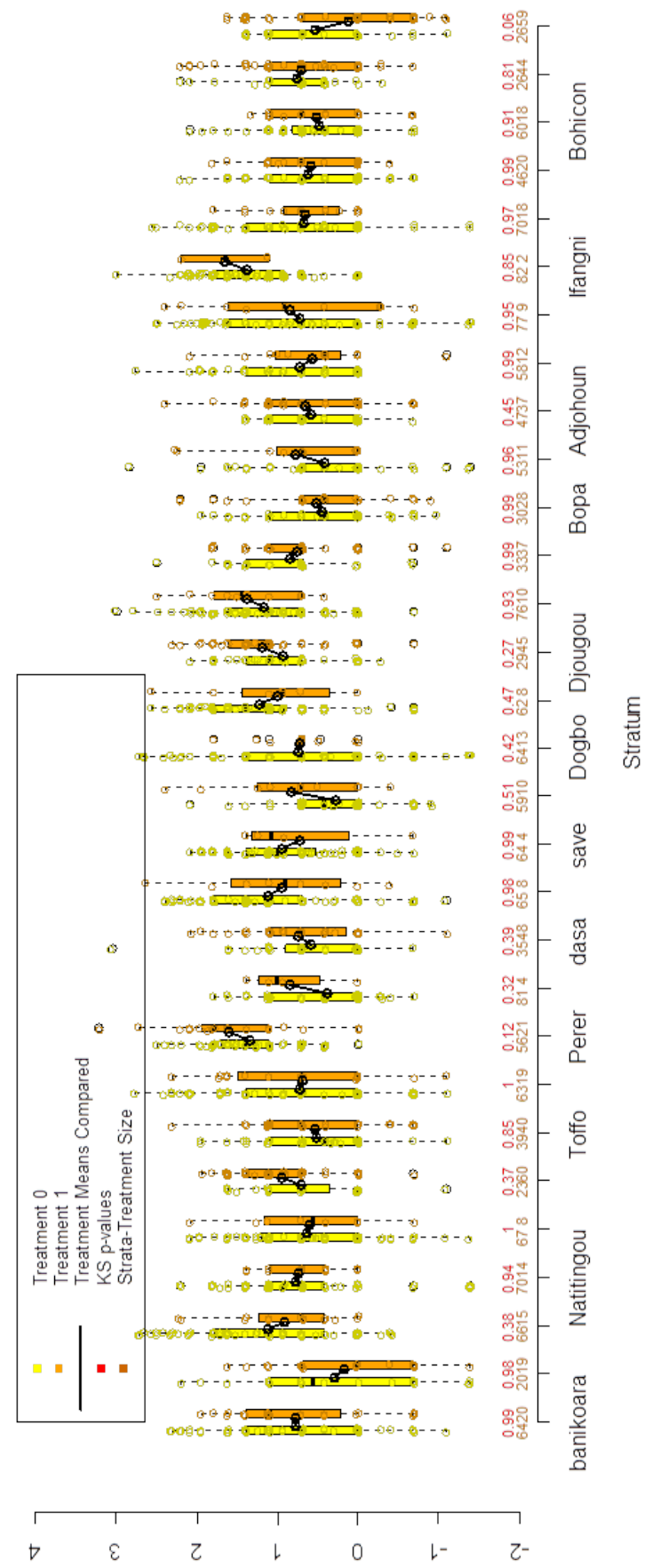

Source: Post-electoral Survey Benin 2011. 
Table 2: Matching Estimates: Turnout

\begin{tabular}{lccc}
\hline \hline & Genetic & Nearest & CEM \\
\hline \hline & $(1)$ & $(2)$ & $(3)$ \\
\hline DV: Self-Reported Turnout & ATT & ATT & ATT \\
\hline Effect of Private Rewards & 0.014 & 0.011 & -0.076 \\
Standard Error & 0.021 & 0.011 & 0.099 \\
p-val & 0.504 & 0.327 & -0.768 \\
\hline \hline Individual Controls & Yes & Yes & Yes \\
\hline Individual controls include: Age, $\log ($ poverty), Party membership for Yayi ABT or UN, \\
employment status, gender,discussion politics, political participation, \\
agricultural worker, primary education, secondary education, other gifts, campaign useless
\end{tabular}


Table 3: Matching Estimates: Vote Choices

\begin{tabular}{|c|c|c|c|}
\hline & Yayi & $\mathrm{UN}$ & $\mathrm{ABT}$ \\
\hline & $(1)$ & $(2)$ & $(3)$ \\
\hline DV: Vote Choices & $\overline{\mathrm{ATT}}$ & $\overline{\mathrm{ATT}}$ & ATT \\
\hline \multicolumn{4}{|c|}{ Genetic Matching } \\
\hline Effect of Private Rewards & -0.0276 & 0.02 & 0.01 \\
\hline Standard Error & 0.013 & 0.02 & 0.01 \\
\hline p-val & 0.034 & 0.966 & 1.021 \\
\hline \multicolumn{4}{|c|}{ Nearest Matching } \\
\hline Effect of Private Rewards & 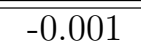 & -0.006 & 0.043 \\
\hline Standard Error & 0.020 & 0.048 & 0.026 \\
\hline p-val & -0.091 & -0.138 & 1.644 \\
\hline \multicolumn{4}{|c|}{ CEM Matching } \\
\hline Effect of Private Rewards & 0.005 & -0.076 & na \\
\hline Standard Error & 0.052 & 0.099 & na \\
\hline p-val & 0.096 & -0.768 & na \\
\hline Individual Controls & Yes & Yes & $\overline{\mathrm{na}}$ \\
\hline
\end{tabular}


Table 4: Matching Estimates: Kenya Afrobarometer Survey

\begin{tabular}{|c|c|c|c|c|}
\hline & Turnout & ODM & $\mathrm{PNU}$ & KANU \\
\hline & $(1)$ & $(2)$ & $(3)$ & $(4)$ \\
\hline DV: Vote Choices & ATT & ATT & ATT & $\overline{\mathrm{ATT}}$ \\
\hline \multicolumn{5}{|c|}{ Exact Matching } \\
\hline Effect of Private Rewards & 0.035 & 0.03 & 0.008 & -0.007 \\
\hline Standard Error & 0.025 & 0.022 & 0.02 & 0.007 \\
\hline T-Stat & 1.375 & 1.33 & 0.43 & -0.943 \\
\hline \multicolumn{5}{|c|}{ Genetic Matching } \\
\hline Effect of Private Rewards & 0.134 & 5.27 & 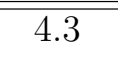 & $\begin{array}{l}-81.9 \\
\end{array}$ \\
\hline Standard Error & 0.258 & 3.45 & 3.39 & 34733.4 \\
\hline T-Stat & 0.520 & 1.52 & 1.27 & -0.002 \\
\hline Individual Controls & Yes & Yes & Yes & $\overline{\text { Yes }}$ \\
\hline
\end{tabular}


Table 5: Probit Estimates: Cash Handouts and Electoral Behavior

\begin{tabular}{|c|c|c|c|c|}
\hline & Turnout & Vote Yayi & Vote UN & Vote ABT \\
\hline Money & $\begin{array}{l}0.210^{*} \\
(0.109)\end{array}$ & $\begin{array}{c}-0.525 * * * \\
(0.0783)\end{array}$ & $\begin{array}{c}0.0209 \\
(0.0670)\end{array}$ & $\begin{array}{c}0.357^{* * *} \\
(0.108)\end{array}$ \\
\hline Log(Poverty) & $\begin{array}{l}0.146^{* *} \\
(0.0577)\end{array}$ & $\begin{array}{c}0.0270 \\
(0.0427)\end{array}$ & $\begin{array}{c}-0.0113 \\
(0.0397)\end{array}$ & $\begin{array}{l}0.160^{* *} \\
(0.0666)\end{array}$ \\
\hline Age & $\begin{array}{c}0.00246 \\
(0.00331)\end{array}$ & $\begin{array}{c}-0.00179 \\
(0.00241)\end{array}$ & $\begin{array}{c}0.00127 \\
(0.00226)\end{array}$ & $\begin{array}{c}0.00413 \\
(0.00354)\end{array}$ \\
\hline Female & $\begin{array}{c}-0.0181 \\
(0.101)\end{array}$ & $\begin{array}{l}-0.0365 \\
(0.0785)\end{array}$ & $\begin{array}{c}0.0159 \\
(0.0698)\end{array}$ & $\begin{array}{c}0.141 \\
(0.116)\end{array}$ \\
\hline Primary & $\begin{array}{r}-0.0508 \\
(0.113)\end{array}$ & $\begin{array}{c}-0.114 \\
(0.0834)\end{array}$ & $\begin{array}{c}-0.104 \\
(0.0774)\end{array}$ & $\begin{array}{c}0.152 \\
(0.125)\end{array}$ \\
\hline Secondary & $\begin{array}{c}0.00791 \\
(0.128)\end{array}$ & $\begin{array}{c}-0.338^{* * *} \\
(0.0988)\end{array}$ & $\begin{array}{c}0.0470 \\
(0.0854)\end{array}$ & $\begin{array}{c}0.176 \\
(0.146)\end{array}$ \\
\hline Ethnicity Fon & $\begin{array}{l}0.189^{* *} \\
(0.0917)\end{array}$ & $\begin{array}{c}-1.063^{* * *} \\
(0.0747)\end{array}$ & $\begin{array}{l}1.035^{* * *} \\
(0.0602)\end{array}$ & $\begin{array}{c}-1.675^{* * *} \\
(0.243)\end{array}$ \\
\hline Party - UN & $\begin{array}{c}-0.00165 \\
(0.362)\end{array}$ & $\begin{array}{c}-1.592^{* * *} \\
(0.472)\end{array}$ & $\begin{array}{c}1.753^{* * *} \\
(0.232)\end{array}$ & . \\
\hline Party - ABT & $\begin{array}{l}-0.418 \\
(0.574)\end{array}$ & . & . & $\begin{array}{c}2.221^{* * *} \\
(0.450)\end{array}$ \\
\hline Party - Yayi & $\begin{array}{l}-0.161 \\
(0.306)\end{array}$ & $\begin{array}{l}-0.0154 \\
(0.169)\end{array}$ & $\begin{array}{c}-1.301^{* * *} \\
(0.272)\end{array}$ & $\begin{array}{l}-0.334 \\
(0.359)\end{array}$ \\
\hline Political Participation? & $\begin{array}{l}0.249^{*} \\
(0.149)\end{array}$ & $\begin{array}{c}0.235^{* * *} \\
(0.0901)\end{array}$ & $\begin{array}{c}0.0257 \\
(0.0835)\end{array}$ & $\begin{array}{c}-0.529 * * * \\
(0.181)\end{array}$ \\
\hline Employed? & $\begin{array}{c}0.0276 \\
(0.0987)\end{array}$ & $\begin{array}{l}-0.0887 \\
(0.0772)\end{array}$ & $\begin{array}{c}-0.209^{* * *} \\
(0.0686)\end{array}$ & $\begin{array}{c}0.310^{* * *} \\
(0.119)\end{array}$ \\
\hline Farmer? & $\begin{array}{l}0.206^{* *} \\
(0.0946)\end{array}$ & $\begin{array}{c}0.587^{* * *} \\
(0.0727)\end{array}$ & $\begin{array}{c}0.0139 \\
(0.0656)\end{array}$ & $\begin{array}{c}-0.242^{* *} \\
(0.108)\end{array}$ \\
\hline Campaign Useless & $\begin{array}{c}-0.335^{* * *} \\
(0.118)\end{array}$ & $\begin{array}{c}-0.832^{* * *} \\
(0.128)\end{array}$ & $\begin{array}{c}0.110 \\
(0.0921)\end{array}$ & $\begin{array}{c}-0.0114 \\
(0.159)\end{array}$ \\
\hline Discuss Politics & $\begin{array}{c}0.415^{* * *} \\
(0.0969)\end{array}$ & $\begin{array}{c}0.0257 \\
(0.0693)\end{array}$ & $\begin{array}{c}0.197^{* * *} \\
(0.0639)\end{array}$ & $\begin{array}{c}-0.0393 \\
(0.105)\end{array}$ \\
\hline Other Gift & $\begin{array}{c}0.343 \\
(0.230)\end{array}$ & $\begin{array}{c}0.273^{* *} \\
(0.123)\end{array}$ & $\begin{array}{l}-0.219^{*} \\
(0.128)\end{array}$ & $\begin{array}{l}0.302^{*} \\
(0.169)\end{array}$ \\
\hline _cons & $\begin{array}{c}0.958^{* * *} \\
(0.182)\end{array}$ & $\begin{array}{c}-0.383^{* * *} \\
(0.141)\end{array}$ & $\begin{array}{c}-0.979 * * * \\
(0.130)\end{array}$ & $\begin{array}{c}-1.830^{* * *} \\
(0.218)\end{array}$ \\
\hline$N$ & 2275 & 2262 & 2262 & 2203 \\
\hline
\end{tabular}


Table 6: Cash Handouts and Electoral Behavior - Probit Estimates - Afrobarometer

\begin{tabular}{lcccc}
\hline \hline & $(1)$ & $(2)$ & $(3)$ & $(4)$ \\
& Turnout & Vote Yayi & Vote UN & Vote ABT \\
\hline Electoral Incentive & $0.341^{* * *}$ & -0.0981 & $0.258^{*}$ & 0.0799 \\
& $(0.119)$ & $(0.0901)$ & $(0.137)$ & $(0.163)$ \\
Poverty & 0.0269 & $0.0636^{* *}$ & -0.0597 & 0.0266 \\
& $(0.0335)$ & $(0.0272)$ & $(0.0421)$ & $(0.0503)$ \\
Preference Yayi & 0.234 & 5.688 & 2.576 & -0.594 \\
& $(0.608)$ & $(95.65)$ & $(133.6)$ & $(0.573)$ \\
Preference ABT & 0.356 & 3.091 & - & $2.335^{* * *}$ \\
& $(0.757)$ & $(95.65)$ & - & $(0.645)$ \\
Preference UN & 0.295 & 3.533 & 5.955 & -0.794 \\
& $(0.643)$ & $(95.65)$ & $(133.6)$ & $(0.631)$ \\
Primary & & & & -0.282 \\
& $-0.362^{*}$ & -0.175 & $0.718^{* *}$ & $(0.262)$ \\
Secondary & $(0.219)$ & $(0.163)$ & $(0.282)$ & -0.240 \\
& & & & $(0.256)$ \\
Constant & $-0.370^{*}$ & -0.0104 & $0.553^{* *}$ & $-1.655^{* *}$ \\
& $(0.216)$ & $(0.161)$ & $(0.276)$ & $(0.795)$ \\
\hline \hline & 1.030 & -5.190 & -5.212 & 1088 \\
\hline \hline
\end{tabular}

Standard errors in parentheses

${ }^{*} p<0.10,{ }^{* *} p<0.05,{ }^{* * *} p<0.01$

Additional controls: No formal education? Vote is secret? Subjective Poverty assessment

Additional controls: urban; cash income; no party preference; female; age; preference democracy 
Table 7: Cash Handouts and Electoral Behavior - Probit Estimates - Kenya Afrobarometer

\begin{tabular}{|c|c|c|c|c|}
\hline & $\begin{array}{c}\text { (1) } \\
\text { Turnout }\end{array}$ & $\begin{array}{c}(2) \\
\text { VoteKanu }\end{array}$ & $\begin{array}{c}(3) \\
\text { VoteODM }\end{array}$ & $\begin{array}{c}(4) \\
\text { VotePNU }\end{array}$ \\
\hline Electoral Incentive & $\begin{array}{c}0.222 * * * \\
(0.0744)\end{array}$ & $\begin{array}{c}0.157 \\
(0.237)\end{array}$ & $\begin{array}{l}0.180^{* *} \\
(0.0903)\end{array}$ & $\begin{array}{c}0.208^{* *} \\
(0.102)\end{array}$ \\
\hline Democracy & $\begin{array}{c}0.510^{* * *} \\
(0.0844)\end{array}$ & $\begin{array}{c}1.081^{* *} \\
(0.444)\end{array}$ & $\begin{array}{r}-0.0230 \\
(0.105)\end{array}$ & $\begin{array}{c}0.322^{* * *} \\
(0.123)\end{array}$ \\
\hline Cash Income & $\begin{array}{c}0.231^{* * *} \\
(0.0724)\end{array}$ & $\begin{array}{l}0.0742 \\
(0.232)\end{array}$ & $\begin{array}{c}-0.322^{* * *} \\
(0.0876)\end{array}$ & $\begin{array}{c}0.632^{* * *} \\
(0.101)\end{array}$ \\
\hline Age & $\begin{array}{c}0.0551^{* * *} * \\
(0.00376)\end{array}$ & $\begin{array}{r}-0.000690 \\
(0.00661)\end{array}$ & $\begin{array}{c}0.00220 \\
(0.00198)\end{array}$ & $\begin{array}{c}0.00303^{* * *} \\
(0.00112)\end{array}$ \\
\hline Primary & $\begin{array}{c}0.813^{*} \\
(0.459)\end{array}$ & $\begin{array}{c}-0.0353 \\
(1.109)\end{array}$ & $\begin{array}{c}0.186 \\
(0.505)\end{array}$ & $\begin{array}{c}-0.00154 \\
(0.578)\end{array}$ \\
\hline Secondary & $\begin{array}{c}0.685 \\
(0.460)\end{array}$ & $\begin{array}{c}-0.561 \\
(1.125)\end{array}$ & $\begin{array}{c}0.433 \\
(0.504)\end{array}$ & $\begin{array}{l}-0.305 \\
(0.579)\end{array}$ \\
\hline University & $\begin{array}{c}1.006^{* *} \\
(0.469)\end{array}$ & $\begin{array}{c}-1.300 \\
(1.223)\end{array}$ & $\begin{array}{c}0.439 \\
(0.514)\end{array}$ & $\begin{array}{c}-0.130 \\
(0.587)\end{array}$ \\
\hline Prefer KANU & $\begin{array}{c}0.484 \\
(0.325)\end{array}$ & $\begin{array}{c}3.336^{* * *} \\
(0.453)\end{array}$ & $\begin{array}{c}-1.388^{* * *} \\
(0.468)\end{array}$ & $\begin{array}{l}-0.235 \\
(0.504)\end{array}$ \\
\hline Prefer ODM & $\begin{array}{c}0.133^{*} \\
(0.0782)\end{array}$ & $\begin{array}{l}-0.678 \\
(0.443)\end{array}$ & $\begin{array}{c}2.177^{* * * *} \\
(0.137)\end{array}$ & $\begin{array}{c}-0.639^{* * *} \\
(0.242)\end{array}$ \\
\hline Prefer PNU & $\begin{array}{c}0.313^{* * *} \\
(0.105)\end{array}$ & . & $\begin{array}{c}-1.276^{* * *} \\
(0.165)\end{array}$ & $\begin{array}{c}2.433^{* * *} \\
(0.193)\end{array}$ \\
\hline Poverty & $\begin{array}{c}0.0615^{* *} \\
(0.0258)\end{array}$ & $\begin{array}{l}-0.0627 \\
(0.0872)\end{array}$ & $\begin{array}{c}0.0489 \\
(0.0319)\end{array}$ & $\begin{array}{c}-0.0610^{*} \\
(0.0367)\end{array}$ \\
\hline Poverty Subjective & $\begin{array}{c}0.0125 \\
(0.0110)\end{array}$ & $\begin{array}{c}0.0112 \\
(0.0316)\end{array}$ & $\begin{array}{c}0.0316^{* *} \\
(0.0129)\end{array}$ & $\begin{array}{c}0.0170 \\
(0.0144)\end{array}$ \\
\hline No preference & & $\begin{array}{c}0.282 \\
(0.339)\end{array}$ & $\begin{array}{l}-0.171 \\
(0.115)\end{array}$ & $\begin{array}{c}0.961^{* * *} \\
(0.186)\end{array}$ \\
\hline Constant & $\begin{array}{c}-3.072^{* * *} \\
(0.545)\end{array}$ & $\begin{array}{c}-2.908^{* *} \\
(1.472)\end{array}$ & $\begin{array}{c}-1.434^{* *} \\
(0.591)\end{array}$ & $\begin{array}{c}-1.955^{* * *} \\
(0.685)\end{array}$ \\
\hline$N$ & 1922 & 1326 & 1597 & 1597 \\
\hline
\end{tabular}


Table 8: Determinants of Cash Handouts - Probit Estimates

\begin{tabular}{|c|c|c|}
\hline & "Receive Handout? & 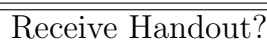 \\
\hline Log(Poverty) & $\begin{array}{l}0.00516 \\
(0.0445)\end{array}$ & $\begin{array}{c}-0.0939^{* *} \\
(0.0384)\end{array}$ \\
\hline Age & $\begin{array}{l}-0.00327 \\
(0.00243)\end{array}$ & $\begin{array}{c}-0.00120 \\
(0.00219)\end{array}$ \\
\hline Female & $\begin{array}{c}-0.0443 \\
(0.0733)\end{array}$ & $\begin{array}{c}0.00203 \\
(0.0672)\end{array}$ \\
\hline Primary? & $\begin{array}{l}-0.0919 \\
(0.0835)\end{array}$ & $\begin{array}{l}-0.0819 \\
(0.0734)\end{array}$ \\
\hline Secondary? & $\begin{array}{c}-0.147 \\
(0.0915)\end{array}$ & $\begin{array}{c}-0.0646 \\
(0.0823)\end{array}$ \\
\hline Ethnicity Fon & $\begin{array}{c}0.126 \\
(0.126)\end{array}$ & $\begin{array}{c}0.212^{* * *} \\
(0.0579)\end{array}$ \\
\hline Party - UN & $\begin{array}{c}0.0177 \\
(0.197)\end{array}$ & $\begin{array}{c}0.447^{* * *} \\
(0.168)\end{array}$ \\
\hline Party - ABT & $\begin{array}{c}0.240 \\
(0.388)\end{array}$ & $\begin{array}{c}0.560 \\
(0.368)\end{array}$ \\
\hline Party - Yayi & $\begin{array}{c}0.209 \\
(0.170)\end{array}$ & $\begin{array}{c}0.378^{* *} \\
(0.155)\end{array}$ \\
\hline Political Participation & $\begin{array}{c}0.160^{*} \\
(0.0931)\end{array}$ & $\begin{array}{l}-0.0869 \\
(0.0829)\end{array}$ \\
\hline Employed? & $\begin{array}{c}0.0937 \\
(0.0766)\end{array}$ & $\begin{array}{c}0.126^{*} \\
(0.0672)\end{array}$ \\
\hline Farmer? & $\begin{array}{c}0.0703 \\
(0.0753)\end{array}$ & $\begin{array}{c}0.213^{* * *} \\
(0.0627)\end{array}$ \\
\hline Campaign Useless? & $\begin{array}{c}-0.350^{* * *} \\
(0.111)\end{array}$ & $\begin{array}{c}-0.452^{* * *} \\
(0.0989)\end{array}$ \\
\hline Discuss Politics & $\begin{array}{c}0.243^{* * *} \\
(0.0705)\end{array}$ & $\begin{array}{c}0.276^{* * *} \\
(0.0612)\end{array}$ \\
\hline Other Gifts? & $\begin{array}{c}0.404^{* * *} \\
(0.124)\end{array}$ & $\begin{array}{c}0.286^{* * *} \\
(0.107)\end{array}$ \\
\hline Constant & $\begin{array}{c}-0.792^{* * *} \\
(0.195)\end{array}$ & $\begin{array}{c}-0.836 * * * \\
(0.124)\end{array}$ \\
\hline$N$ & 2272 & 2272 \\
\hline Constituency FE & Yes & No \\
\hline
\end{tabular}


Table 9: Determinants of Cash Handouts - Probit Estimates - Afrobarometer

\begin{tabular}{|c|c|c|c|c|c|c|}
\hline & $\begin{array}{c}(1) \\
\text { Any Offer }\end{array}$ & $\begin{array}{c}(2) \\
\text { Any Offer }\end{array}$ & $\begin{array}{c}(3) \\
\text { One Offer }\end{array}$ & $\begin{array}{c}(4) \\
\text { One Offer }\end{array}$ & $\begin{array}{c}(5) \\
\text { Two Offer }\end{array}$ & $\begin{array}{c}(6) \\
\text { Two Offer }\end{array}$ \\
\hline Poverty & $\begin{array}{c}0.0284 \\
(0.0259)\end{array}$ & $\begin{array}{c}0.0203 \\
(0.0307)\end{array}$ & $\begin{array}{r}-0.00272 \\
(0.0300)\end{array}$ & $\begin{array}{l}-0.0416 \\
(0.0360)\end{array}$ & $\begin{array}{c}0.0412 \\
(0.0296)\end{array}$ & $\begin{array}{l}0.0589^{*} \\
(0.0349)\end{array}$ \\
\hline secret & $\begin{array}{c}0.330 * * \\
(0.144)\end{array}$ & $\begin{array}{l}0.278^{*} \\
(0.152)\end{array}$ & $\begin{array}{l}0.305^{*} \\
(0.170)\end{array}$ & $\begin{array}{c}0.358 * * \\
(0.178)\end{array}$ & $\begin{array}{c}0.174 \\
(0.170)\end{array}$ & $\begin{array}{l}0.0589 \\
(0.183)\end{array}$ \\
\hline Poverty (subjective) & $\begin{array}{c}-0.0198^{*} \\
(0.0118)\end{array}$ & $\begin{array}{c}-0.0279 * * \\
(0.0130)\end{array}$ & $\begin{array}{c}0.0402^{* * *} \\
(0.0136)\end{array}$ & $\begin{array}{c}0.0374^{* *} \\
(0.0147)\end{array}$ & $\begin{array}{c}-0.0662^{* * *} \\
(0.0138)\end{array}$ & $\begin{array}{c}-0.0716^{* * *} \\
(0.0151)\end{array}$ \\
\hline Prefer Yayi? & $\begin{array}{l}-0.205 \\
(0.439)\end{array}$ & $\begin{array}{l}-0.107 \\
(0.459)\end{array}$ & $\begin{array}{c}0.521 \\
(0.577)\end{array}$ & $\begin{array}{c}0.441 \\
(0.602)\end{array}$ & $\begin{array}{c}-0.700 \\
(0.446)\end{array}$ & $\begin{array}{c}-0.650 \\
(0.470)\end{array}$ \\
\hline Prefer ABT? & $\begin{array}{l}-0.137 \\
(0.506)\end{array}$ & $\begin{array}{c}0.226 \\
(0.540)\end{array}$ & $\begin{array}{c}0.530 \\
(0.639)\end{array}$ & $\begin{array}{c}0.647 \\
(0.670)\end{array}$ & $\begin{array}{l}-0.459 \\
(0.520)\end{array}$ & $\begin{array}{l}-0.202 \\
(0.558)\end{array}$ \\
\hline Prefer UN? & $\begin{array}{l}0.0278 \\
(0.453)\end{array}$ & $\begin{array}{c}0.104 \\
(0.474)\end{array}$ & $\begin{array}{r}-0.0957 \\
(0.600)\end{array}$ & $\begin{array}{c}-0.133 \\
(0.628)\end{array}$ & $\begin{array}{l}0.0683 \\
(0.458)\end{array}$ & $\begin{array}{c}0.103 \\
(0.484)\end{array}$ \\
\hline Cash Income? & $\begin{array}{c}-0.480^{* * *} \\
(0.112)\end{array}$ & $\begin{array}{c}-0.523^{* * *} \\
(0.124)\end{array}$ & $\begin{array}{c}-0.239^{*} \\
(0.132)\end{array}$ & $\begin{array}{c}-0.224 \\
(0.148)\end{array}$ & $\begin{array}{c}-0.464^{* * *} \\
(0.131)\end{array}$ & $\begin{array}{c}-0.524^{* * *} \\
(0.146)\end{array}$ \\
\hline Primary? & $\begin{array}{c}0.272^{*} \\
(0.154)\end{array}$ & $\begin{array}{c}0.130 \\
(0.164)\end{array}$ & $\begin{array}{c}0.250 \\
(0.188)\end{array}$ & $\begin{array}{c}0.311 \\
(0.198)\end{array}$ & $\begin{array}{c}0.190 \\
(0.176)\end{array}$ & $\begin{array}{r}-0.0708 \\
(0.190)\end{array}$ \\
\hline Secondary? & $\begin{array}{l}0.288^{*} \\
(0.153)\end{array}$ & $\begin{array}{c}0.119 \\
(0.162)\end{array}$ & $\begin{array}{c}0.333^{*} \\
(0.186)\end{array}$ & $\begin{array}{l}0.384^{*} \\
(0.197)\end{array}$ & $\begin{array}{c}0.122 \\
(0.174)\end{array}$ & $\begin{array}{c}-0.190 \\
(0.188)\end{array}$ \\
\hline Value Democracy? & $\begin{array}{c}-0.228^{* *} \\
(0.0947)\end{array}$ & $\begin{array}{c}-0.251^{* *} \\
(0.105)\end{array}$ & $\begin{array}{c}-0.149 \\
(0.108)\end{array}$ & $\begin{array}{c}-0.157 \\
(0.119)\end{array}$ & $\begin{array}{l}-0.168 \\
(0.107)\end{array}$ & $\begin{array}{l}-0.183 \\
(0.122)\end{array}$ \\
\hline Constant & $\begin{array}{l}0.0489 \\
(0.518) \\
\end{array}$ & $\begin{array}{c}0.113 \\
(0.619)\end{array}$ & $\begin{array}{c}-1.651^{* *} \\
(0.661)\end{array}$ & $\begin{array}{l}-5.393 \\
(71.95)\end{array}$ & $\begin{array}{c}0.146 \\
(0.546)\end{array}$ & $\begin{array}{c}0.687 \\
(0.661)\end{array}$ \\
\hline$N$ & 1088 & 1088 & 1086 & 1086 & 1086 & 1073 \\
\hline
\end{tabular}

Standard errors in parentheses

${ }^{*} p<0.10,{ }^{* *} p<0.05,{ }^{* * *} p<0.01$

Additional controls: No formal education, Urban, No party preference, Female, Age. 
Table 10: Matching Estimates: Afrobarometer Survey

\begin{tabular}{lcccc}
\hline & Turnout & Yayi & UN & ABT \\
\hline \hline & $(1)$ & $(2)$ & $(3)$ & $(4)$ \\
\hline \hline DV: Vote Choices & ATT & ATT & ATT & ATT \\
\hline \multicolumn{5}{c}{ Exact Matching } \\
\hline Effect of Private Rewards & 0.012 & 0.051 & -0.01 & 0.019 \\
Standard Error & 0.027 & 0.037 & 0.024 & 0.014 \\
T-Stat & 0.471 & 1.37 & -0.66 & 1.28 \\
\hline \hline
\end{tabular}

\begin{tabular}{lcccc}
\hline \hline \multicolumn{5}{c}{ Genetic Matching } \\
\hline \hline Effect of Private Rewards & 0.014 & -0.047 & 0.037 & 0.976 \\
Standard Error & 0.006 & -0.036 & 0.057 & 1.24 \\
T-Stat & 2.36 & -1.303 & 0.001 & 0.787 \\
\hline \hline Individual Controls & Yes & Yes & Yes & Yes \\
\hline \hline
\end{tabular}

Individual controls include: Age, Age2, Poverty Index,

Ethnicity, Preference for Yayi, ABT and UN, Gender and Education

Table 11: Matching Estimates of Multiple Offers: Afrobarometer Survey

\begin{tabular}{lcccc}
\hline & Turnout & Yayi & UN & ABT \\
\hline \hline \multicolumn{5}{c}{ Genetic Matching } \\
\hline \hline DV: Vote Choices & ATT & ATT & ATT & ATT \\
\hline \hline Effect of One Offer & 0.812 & 0.146 & -104.5 & 1.91 \\
Standard Error & 0.784 & 0.48 & 60818 & 5.662 \\
Z-Value & 1.03 & 0.30 & -0.002 & 0.003 \\
\hline \hline Effect of Two or More & -1.50 & -0.08 & 0.26 & -0.689 \\
Standard Error & 1.10 & 0.07 & 5676 & 1126 \\
Z value & -1.36 & -1.15 & 0.00 & 0.00 \\
\hline \hline \multicolumn{5}{c}{ Exact Matching } \\
\hline \hline Effect of One Offer & 0.08 & 0.03 & 0.03 & 0.04 \\
Standard Error & 0.02 & 0.04 & 0.02 & 0.02 \\
T-Stat & 2.89 & 0.68 & 1.42 & 2.57 \\
\hline \hline Effect of Two or More & -0.03 & -0.12 & 0.077 & 0.009 \\
Standard Error & 0.03 & 0.04 & 0.03 & 0.01 \\
T-Stat & -1.09 & -2.76 & 2.56 & 0.57 \\
\hline \hline Individual Controls & Yes & Yes & Yes & Yes \\
\hline \hline
\end{tabular}

Individual controls include: Age, Age2, Poverty Index,

Ethnicity, Preference for Yayi, ABT and UN, Gender and Education 